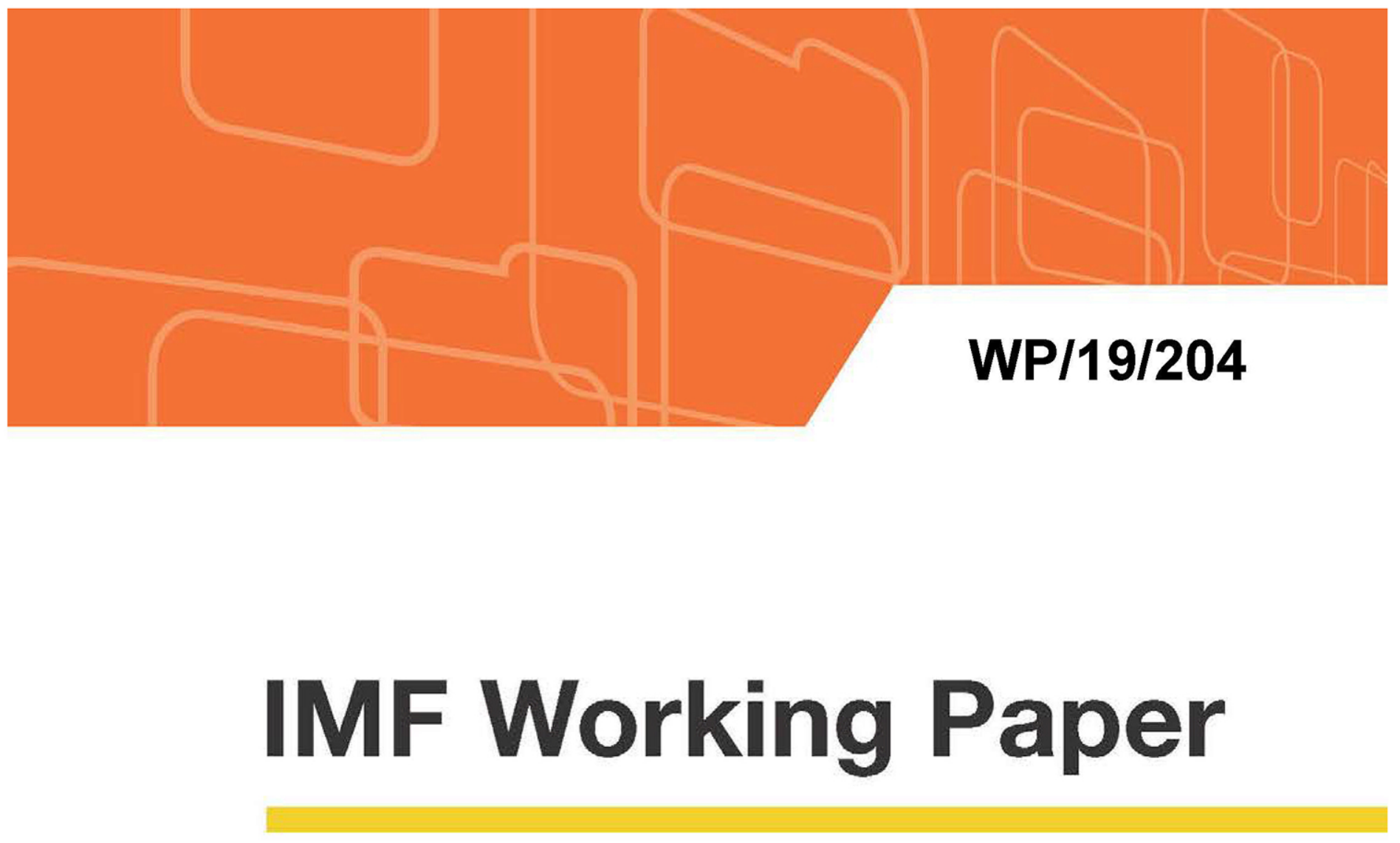

\title{
Multiple Dimensions of Human Development Index and Public Social Spending for Sustainable Development
}

by lana Paliova, Robert McNown and Grant Nülle

IMF Working Papers describe research in progress by the author(s) and are published to elicit comments and to encourage debate. The views expressed in IMF Working Papers are those of the author(s) and do not necessarily represent the views of the IMF, its Executive Board, or IMF management. 


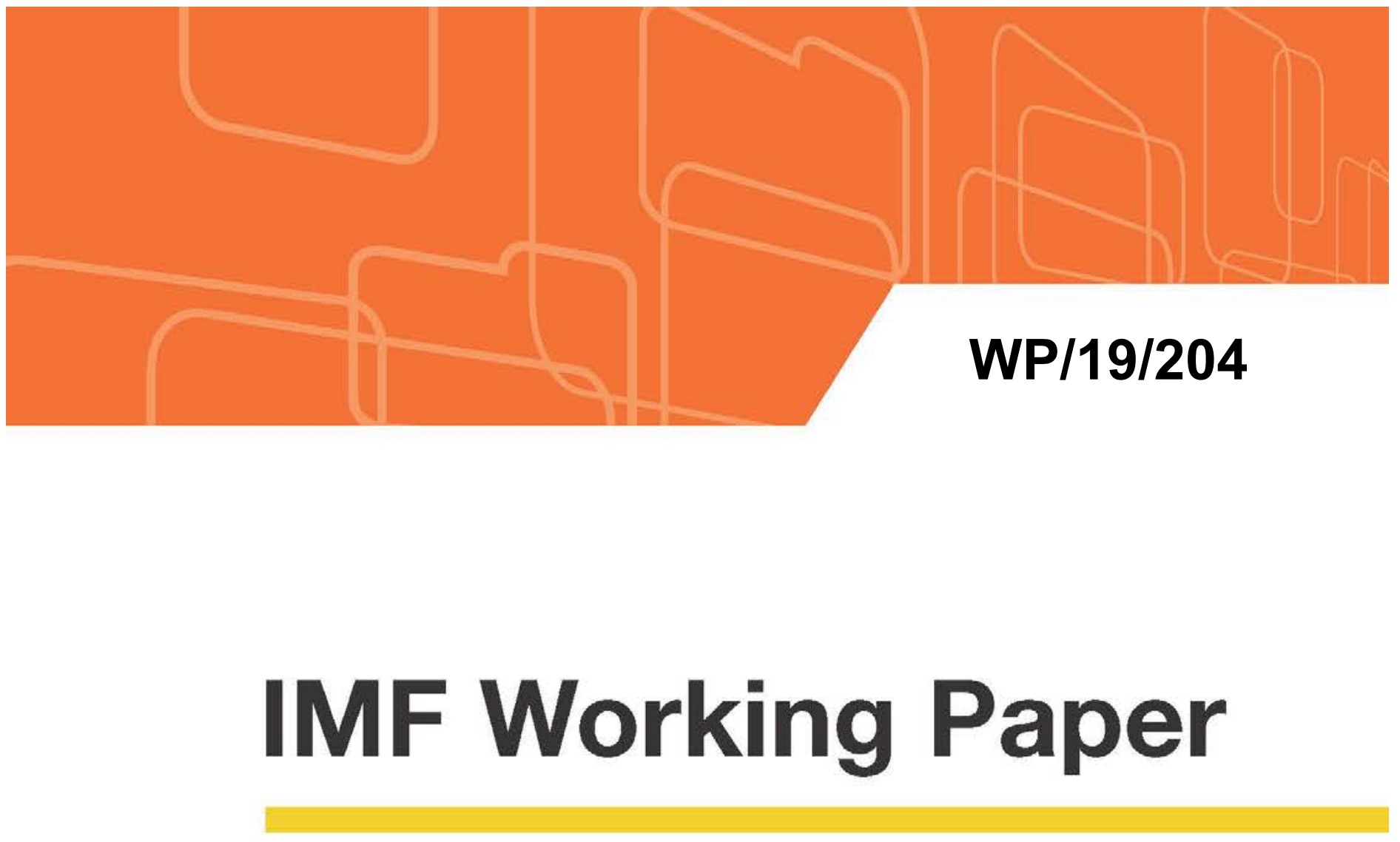

\section{Multiple Dimensions of Human Development Index and Public Social Spending for Sustainable Development}

by lana Paliova, Robert McNown and Grant Nülle

IMF Working Papers describe research in progress by the author(s) and are published to elicit comments and to encourage debate. The views expressed in IMF Working Papers are those of the author(s) and do not necessarily represent the views of the IMF, its Executive Board, or IMF management.

$$
\text { I N T ER N A T I O N A L M O NETAR Y FU N D }
$$




\title{
IMF Working Paper
}

Statistics Department

\section{Multiple Dimensions of Human Development Index and Public Social Spending for Sustainable Development}

Prepared by

\author{
Iana Paliova, Robert McNown, and Grant Nülle ${ }^{1}$ \\ Authorized for distribution by Rainer Koehler
}

September 2019

\begin{abstract}
IMF Working Papers describe research in progress by the author(s) and are published to elicit comments and to encourage debate. The views expressed in IMF Working Papers are those of the author(s) and do not necessarily represent the views of the IMF, its Executive Board, or IMF management.
\end{abstract}

\begin{abstract}
Multidimensional assessment of human development is increasingly recognized as playing an important role in assessing well-being. The focus of analysis is on the indicators measuring the three dimensions of Human Development Index (HDI) - standard of living, education and health, and their relationship with public social spending for achieving the 2030 Agenda for Sustainable Development. The study estimates the effects of public social spending on gross national income (GNI) per capita (in PPP in \$), expected years of schooling and life expectancy for a sample of 68 countries. The relationship is robust to controlling for a variety of factors and the estimated magnitudes suggest a positive long-run effect of public educational spending on GNI per capita, public educational spending on expected years of schooling, and public health expenditures on life expectancy.

JEL Classification Numbers: O15, H5, I1, I2, I3

Keywords: Human Development, Well-being, Public Expenditure Authors’ E-Mail Address: ipaliova@imf.org; mcnownr@gmail.com; grantnulle@gmail.com

\footnotetext{
${ }^{1}$ Robert McNown is Professor Emeritus at Department of Economics, University of Colorado Boulder and President, JTC Econometrics LLC. Grant Nülle is Deputy Director of Arizona Department of Revenue. We wish to thank Messrs. Rainer Koehler, Zaijin Zhan, Andrew Kitili, Gary Jones and Ms. Gloria Addison from the IMF's Statistics Department (STA), Mr. David Coady and Ms. Mercedes Garcia-Escribano from the IMF's Fiscal Affairs Department (FAD) for their continuous support during the research project. We are grateful to colleagues in the IMF, especially to Ms. Tewodaj Mogues and Mr. Emmanouil Kitsios (FAD), Messrs Roland Kpodar (SPR) and Laurent Kemoe (EUR), Mmes. Irene Yackovlev (SPR), Claudia Berg (RES), Oana Luca (EUR), Yingbin Xiao and Diane Kostroch (STA) for their insightful reviews of the paper. Special thanks to Mr. Xingwei Hu (IT Officer) and Ms. Christina Hu (STA) for data support.
} 


\section{Contents}

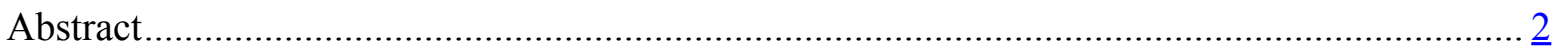

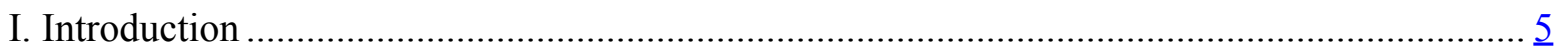

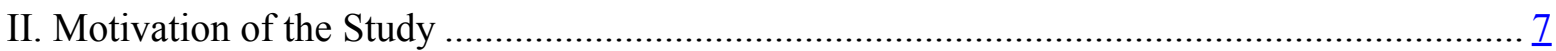

A. Human Development Index and Inequality ........................................................

B. Public Social Spending for the Agenda 2030 for Sustainable Development....................... $\underline{8}$

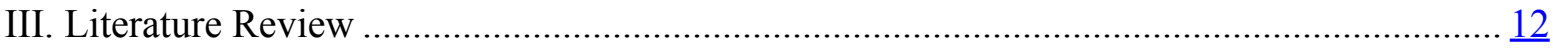

IV. Econometric Model And Data............................................................................... 13

A. Econometric Model and Methodology .................................................................. 13

B. Dependent and Explanatory variables ................................................................... 15

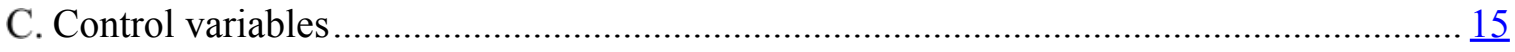

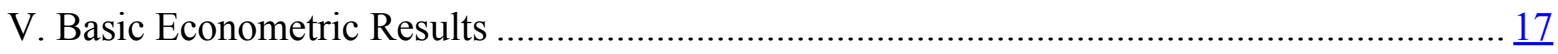

A. GNI per Capita and Public Social Expenditures......................................................... 18

B. Expected Years of Schooling and Public Educational Spending ..................................... 19

C. Life Expectancy and Public Health Spending .......................................................... 20

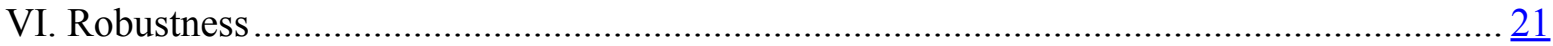

A. GNI per Capita and Public Social Expenditures...................................................... 21

B. Expected Years of Schooling and Public Educational Spending................................... 25

C. Life Expectancy and Public Health Spending ........................................................ $\underline{26}$

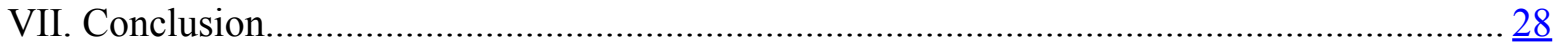

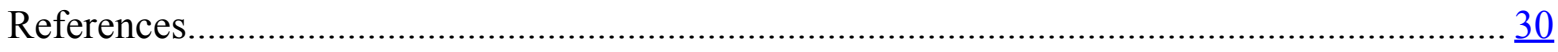

Appendix I. Countries Reported For The IMF GFS Yearbook Used The Sample..................... $\underline{34}$

Appendix II. Data Methodology and Tests..................................................................... $\underline{36}$

Appendix III. Public Social Spending by Regions and Level of Income (figures) ................... $\underline{40}$

\section{Tables}

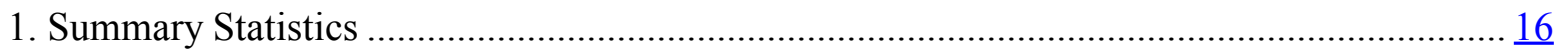

2. Basic Regression Results for GNI per Capita and Public Educational Spending................. 18

3. Basic Regression Results for Expected Years of Schooling.............................................. 20

4. Basic Regression Results for Life Expectancy ............................................................. 21

5. Robustness Checks for GNI and Public Social Spending.............................................. 22

6. Robustness Checks for Expected Years of Schooling .................................................... 25

7. Robustness Checks for Life Expectancy …............................................................. 27

8. GFS Functions of Government for Social Spending (GFSM 2014) ................................... $\underline{36}$

9. Granger Causality Test ....................................................................................................

\section{Figures}

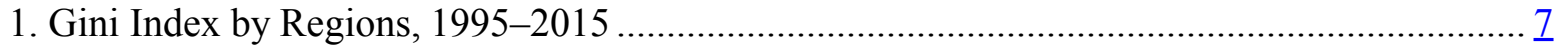

2. Human Development Index by Regions for 2017 .............................................................. $\underline{8}$

3. Government Expenditure per Student in Levels of Education by Regions for 2017

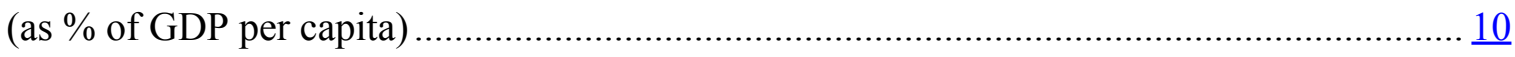

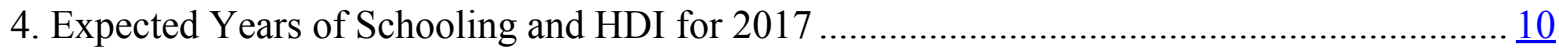

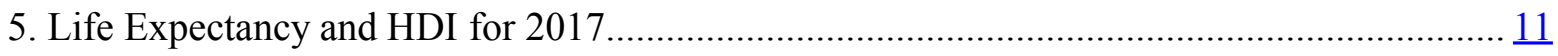

6. Social Protection Spending by Regions for 2016 (percent of GDP) ................................... 40

7. Social Protection by Countries Income Level for 2016 (percent of GDP) ........................... $\underline{40}$ 
8. Educational spending by Regions for 2016 (percent of GDP) ....................................... 41

9. Educational spending by Countries Income Level for 2016 (percent of GDP) ..................... 41

10. Health Spending by Regions for 2016 (percent of GDP) .......................................... 42

11. Health Spending by Countries Income Level for 2016 (percent of GDP).......................... $\underline{42}$ 


\section{INTRODUCTION}

This paper is motivated by the dedication of the International Monetary Fund (IMF) to broaden the focus of its surveillance work to include "emerging macro-critical issues" outside the IMF's traditional remit, including social outcomes of fiscal policy and inequality. In 2015, the IMF committed to "working with its member countries and international partners in the spirit of global cooperation necessary to achieve the Sustainable Development Goals" (Lagarde, 2015) 2 The study uses the IMF Government Finance Statistics Yearbook (GFSY) database, which provides the best-harmonized and documented set of annual fiscal data for the largest number of countries over the largest number of years.

Over the past decades, there has been a growing interest in multidimensional indicators of well-being and their relationship with public spending. Traditionally, the metrics of well-being involves a single dimension, which represents national income, GNI per capita or consumption in cash and kind. In addition to income and consumption, wealth is important, but less frequently used monetary indicator due to data time series constraints for most of the countries. Choosing only one dimension for assessment of human development of the societies implicitly assumes that individuals and households have similar income level and can freely reallocate their resources among consumption, education and health, which is not the case in low income countries. The other indicator for multidimension assessment of well-being is Human Development Index (HDI). The HDI measures human development by average achievement in three basic dimensions - standard of living, education and health, which are assessed by three indicators - GNI per capita (in PPP in \$), expected years of schooling and life expectancy.

Multidimensional indicators ${ }^{3}$ of well-being capture the heterogeneity of countries and access to social public services, including social public expenditures - social protection, healthcare and education. Social protection helps realize the human right to social security and contributes powerfully to reduction of inequality and poverty. Literacy and years of schooling are used as proxies for the levels of knowledge and skills, while life expectancy, together with child mortality and nutrition status approximate the quality of living. Many emerging and developing economies are boldly expanding their social protection and healthcare systems following gradual increases in GNI per capita. The countries are in the process of building up social protection floors as part of comprehensive social safety systems to combat inequality and social exclusion. The long-term objective nature of these measures reflects in the substance matter considered in the assessment process ${ }^{4}$. In this regard, this study seeks to complement the previous studies devoted to well-being in the following respects:

- $\quad$ The focus of empirical analysis is on estimated effects of public social spending on indicators of the three dimensions of HDI in the short and long run for a sample of 68 countries, which regularly report Classification of Functions of Government (COFOG) data for the GFSY database.

\footnotetext{
${ }^{2}$ The IMF and social protection, 2017 Evaluation Report, Independent Evaluation Office p.6-7

${ }^{3}$ The authors opted for HDI as the multidimensional indicator choice over the multidimensional poverty index (MPI) because the HDI addresses more SDGs (four) than the MPI (one). The MPI is produced by the United Nations Development Program and Oxford Poverty and Human Development Initiative that defines poverty. This index is intended to Sustainable Development Goal 1 - to end poverty in all its forms: http://hdr.undp.org/en/2018-MPI.

${ }^{4}$ International Labor Organization, 2014, World Social Protection Report 2014/2015: Building Economic Recovery, Inclusive Development and Social Justice.
} 
- $\quad$ The main study investigates the cross-country relationship between public educational, health, and social protection spending and GNI per capita (in PPP in \$).

- $\quad$ The study also examines to what extent public social spending is subject to a straightforward relationship with expected years of schooling and life expectancy.

Our paper studies the impact of public social spending on GNI per capita (in PPP in \$), expected years of schooling and life expectancy in three steps. First, to have quantitative and qualitative indicators for more countries and dimensions, and following most previous studies, we constructed our panel data for the period 1995-2016 employing data on COFOG data reported in the GFSY database for 68 countries (Appendix 1); data for HDI, GNI per capita (in PPP in \$), expected years of schooling and life expectancy from the United Nations' Global Indicators Database; data for population, population growth, terms of trade, Gini coefficients, and the Worldwide Governance Indicators (WGI) ${ }^{5}$ from the World Bank's Open Data and World Development Indicators (WDI) databases ${ }^{6}$. The study also uses data for inflation and investment rates from the IMF's World Economic Outlook (WEO) database.

Second, we calibrate our model to investigate the causal effect of public social spending on indicators of the HDI dimensions, including unlagged dependent and explanatory variables with country fixed effects to control for country specific factors affecting both public social spending and dimensions of HDI. In order to deal with the potential endogeneity problem of social spending in our regressions like Acemoglu et al. (2008) in their study about the relationship between democracy and GNI per capita, we found that country fixed effects and the inclusion of a lagged explanatory variable are well suited to control for the potential endogeneity and reverse causality. We also add a lagged dependent variable to deal with a spurious regressions problem. To check further the estimations, we implement robustness tests by estimating our equations using the methodology and instrumental variable estimator of Andersen and Hsiao (1982), which was further developed by Arellano and Bond (1991). Similar to Pagano (2004) and Acemoglu et al. (2008) we found that the Generalized Method of Movement (GMM) estimator of Arellano and Bond (1991) as a technique is well suited to control for any measurement error and for any time-invariant omitted variables, and to confirm our results from the specifications with the inclusion of country fixed effects and a lagged dependent variable. We also use the method of instrumental variables to address endogeneity and the Hausman test for endogeneity to test which of the models random or fixed effects is appropriate. The control variables include population, population growth, inflation, investment, terms of trade, literacy rate, voice and accountability, political stability and no violence, government effectiveness, rule of law, regulatory quality, and control of corruption.

Third, our estimated regression coefficients have a positive long-run effect of public educational spending on GNI per capita, but we do not find similar statistical relationship for GNI per capita and public social spending on health and social protection. Our estimations for expected year of schooling and life expectancy as dimensions of human development imply a straightforward relationship with public spending on education and health respectively in the long run.

\footnotetext{
${ }^{5}$ The WGI (World Governance Indicators) are produced by Daniel Kaufmann—affiliated with the Brookings Institution and Natural Resource Governance Institute (NRGI) - and Aart Kraay, affiliated with the World Bank (Development Research Group). The compilers acknowledge financial support from the Knowledge for Change Program of the World Bank. See: https://info.worldbank.org/governance/wgi/\#home

${ }^{6}$ The indicators of the UN organizations, including the World Bank and the IMF International Financial Statistics, are available in the United Nations' database: http://data.un.org/Explorer.aspx?d=WDI; http://hdr.undp.org/en/data\#
} 
The paper is organized as follows: Section II presents the motivation of the paper. Section III reviews the literature on the effect of public spending on social outcomes. Section IV describes the econometric model and data. Section V analyzes the econometric results and robustness checks. Section VI concludes. Appendixes presents the countries in the sample, data methodology, and figures about the share of public social spending as percent of GDP by regions and income level.

\section{Motivation OF The StUdy}

\section{A. Human Development Index and Inequality}

Income inequality is clustered by the regions. The high levels of inequality are recorded in all regions except in the European countries (Figure 1). In our sample countries, Gini coefficients range between 0.27 (high equality) and above 0.66 (high inequality) and tend to exceed variations due to significant economic and political differences among them. Sub-Saharan Africa, North Africa and Middle East, and Asia and Pacific show average Gini coefficients of around 0.48, with increasing inequality in Sub-Saharan Africa over the last decade ${ }^{7}$. The high levels of inequality of 0.50 is recorded in Brazil, Colombia, Honduras, Panama, Guatemala. In Sub-Saharan Africa, income inequality in some countries is above 0.60 (Namibia, South Africa, Zambia) ${ }^{8}$.

Figure 1. Gini Index by Regions, 1995-2015

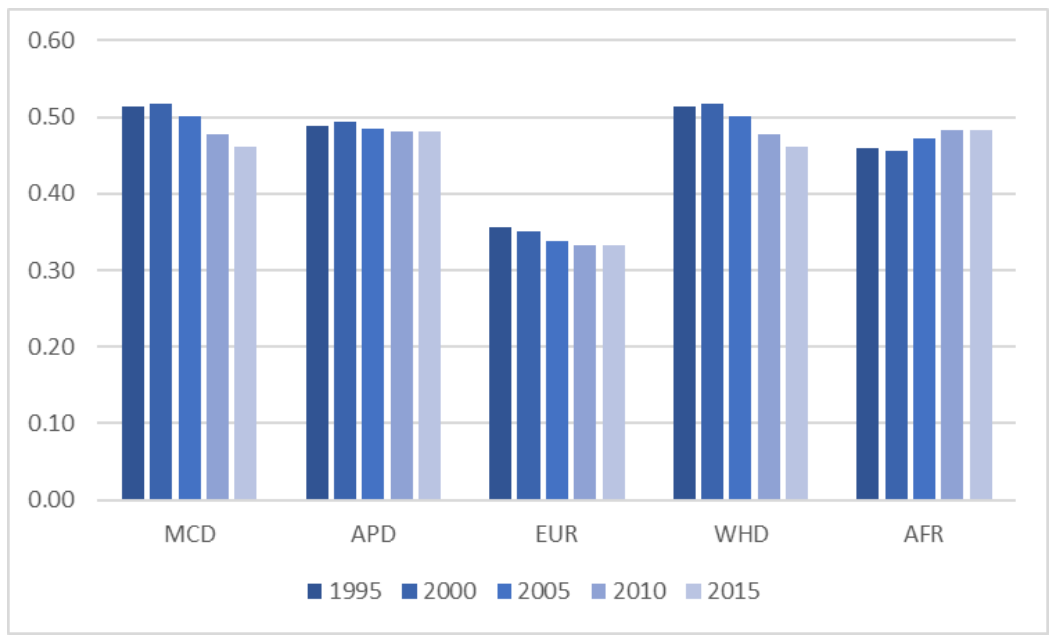

AFR (Sub-Saharan Africa); APD (Asia and Pacific); EUR (Europe), MCD (North Africa and Middle East); WHD (Western Hemisphere). See Appendix 2 about the World Bank's methodology for Gini index used in the study. Source: Authors' estimates from World Bank and Bruegel database ${ }^{9}, 2018$

\footnotetext{
${ }^{7}$ Estimated for the regions by natural logarithms distribution method in Bruegel database at: http://bruegel.org/publications/datasets/global-and-regional-gini-coefficients/

${ }^{8}$ World Bank's database: https://data.worldbank.org/indicator/si.pov.gini

${ }^{9}$ Bruegel database includes the following country groups: 146 countries, 37 Advanced countries, 109 Emerging and developing countries, 18 Emerging and developing Asian countries and ASEAN-5, 32 SubSaharan African countries, 12 Commonwealth of Independent States countries, 28 European Union countries, 27 European Union countries (not including Croatia), 15 European Union countries (members before 2004), 13 European Union countries (members joined in 2004-13), 24 Latin American and the Caribbean countries, 12 Middle East and North African countries: http://bruegel.org/publications/datasets/global-and-regional-ginicoefficients/
} 
Consistent with Kuznets curve hypothesis, the countries with medium and low HDI and high inequality have lower income per capita (Figure 2). Periods of economic growth are usually associated with accelerated economic development and good fiscal stance, but income distribution and inequality do not always improve. Identifying and reorienting the respective social fiscal policies can narrow the human development deficits of those left out ${ }^{10}$. Income redistribution for these countries is crucial to solve inequality problems.

Figure 2. Human Development Index by Regions for 2017

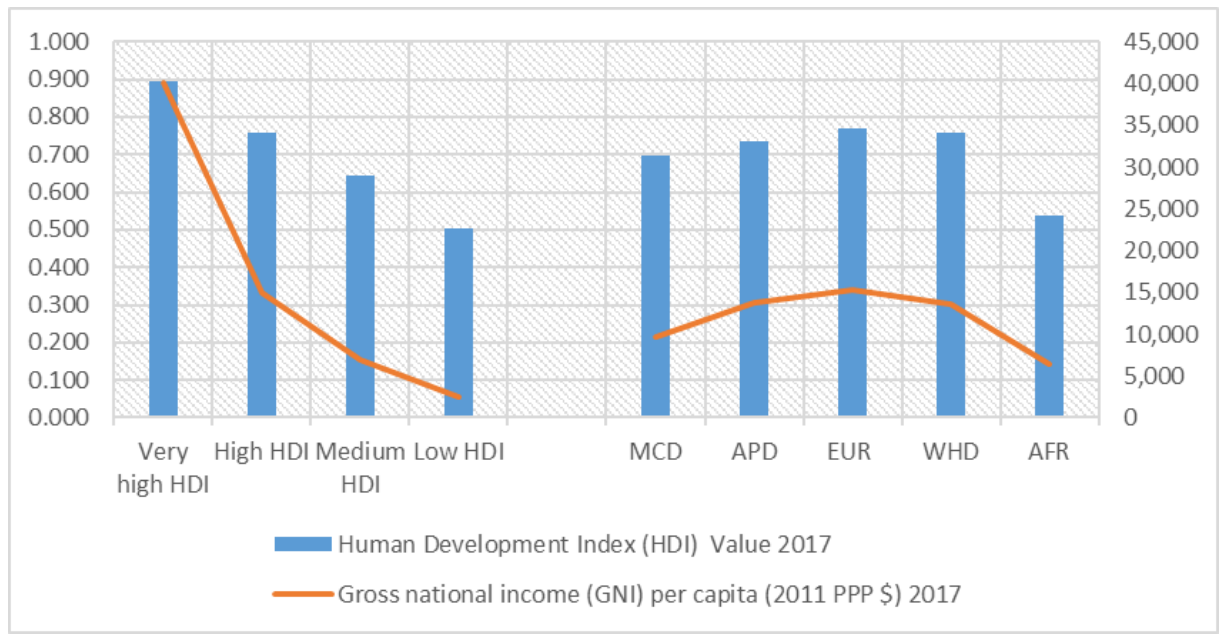

AFR (Sub-Saharan Africa); APD (Asia and Pacific); EUR (Europe), MCD (North Africa and Middle East); WHD (Western Hemisphere). HDI levels are: very high level - above 0.8, high above 0.7 , medium between $0.56-0.7$, and low below 0.56 (see Appendix II).

Source: Authors' estimates from UN database, 2018

\section{B. Public Social Spending for the Agenda 2030 for Sustainable Development}

The 2030 Agenda for Sustainable Development was adopted in 2015 and consists of the 17 Sustainable Development Goals (SDGs) ${ }^{11}$, which provide a blueprint for peace and prosperity for people and the planet, and map to the dimensions of HDI and the Organization for Economic Co-operation and Development (OECD) well-being framework" ${ }^{12}$ The SDGs 1 "End poverty in all its forms everywhere" and 2 "End hunger, achieve food security and improved nutrition and promote sustainable agriculture', on poverty and food respectively, align with GNI per capita, while the SDGs 3 "Ensure healthy lives and promote well-being for all at all age" and 4 "Ensure inclusive and equitable quality education and promote lifelong learning opportunities for all," on health and education, are relevant to life expectancy and expected years of schooling as dimensions of HDI. One of the targets of the Agenda 2030 is to ensure significant mobilization of resources from a variety of sources, including through enhanced development cooperation, in order to provide adequate and predictable means for developing countries to implement programs and policies to end poverty in all its dimensions. The SDGs indicator 1.a.2."Proportion of total government spending on essential services (education, health and

\footnotetext{
${ }^{10}$ United Nations, 2018, UN Human Development Report 2016, http://www.hdr.undp.org/en

${ }^{11}$ United Nations' 2030 Agenda: https://www.un.org/sustainabledevelopment/development-agenda/

12 OECD Better Life Initiative: Measuring Well-Being and Progress: http://www.oecd.org/statistics/better-lifeinitiative.htm
}

(continued...) 
social protection)" is one of the indicators for assessing the achievement of this target in the countries, ${ }^{13}$ which increases the importance of the COFOG data for public policy analysis.

A wide array of public policies, including educational, healthcare and social protection programs, are in the focus of the IMF fiscal surveillance ${ }^{14}$. Around 60 percent of all Article IV consultation reports contained social policy advice ${ }^{15}$. Approximately 10 percent of IMF-supported arrangements during 2006-2015 included structural conditionality explicitly to strengthen or better target social spending. However, to balance efficiency and equity concerns on social spending, the IMF staff paper on Jobs and Growth (and the staff related guidance note) endorses the Nordic countries' "flexicurity" model of protecting workers through social safety nets, including unemployment insurance, educational programs and support of job search rather than high employment protection. Other policies that support long-run poverty reduction, such as government spending on education and health, and programs that boost job creation and economic growth in the long-term are not considered social protection policies in the GFSM 2014, although the 2008 European System of Integrated Social Protection Statistics does.

Social protection in Sub-Saharan Africa covers only 17.8 percent of the population. Regional variations are large, with coverage ranging from 48 percent in South Africa to below 10 percent in a number of West African countries. Significant progress has been achieved for old-age pensions, now covering 29.6 percent of older persons in Africa, but reaching or approaching universal coverage in Botswana, Cabo Verde, Lesotho, Mauritius, Namibia, Seychelles, South Africa, Eswatini and Zanzibar (United Republic of Tanzania) ${ }^{16}$.

Within the last decade there has been an increase in the expenditure committed to education. In most of the emerging and developing economies it reached 4 percent of GDP. While most of the countries in Latin America and the Caribbean and Middle East and North Africa increased investment in education, low-income countries keep spending at around 3 percent in relation to GDP.

\section{Governments in Europe finance more than 80 percent of total education spending ${ }^{17}$.}

Europe has very high share of government expenditures per student in all levels of education, expressed as a percentage of GDP per capita ${ }^{18}$. This explains much better availability and quality of public education in Europe in comparison with other regions. The share of government expenditures in different levels of education is more diverse in other regions. Western Hemisphere shows relatively high level of public spending per student in the tertiary education, but together with South Asia it lags other regions regarding primary and secondary education ${ }^{19}$ (Figure 3).

\footnotetext{
13 The custodian agencies for the data collection are under discussion among agencies (IMF, ILO, UNESCOUIS, WHO).

${ }^{14}$ See Appendix III about the share of public social spending as percent of GDP by regions and income level.

15 The IMF and social protection, 2017 Evaluation Report, Independent Evaluation Office p.21-22, http://www.ieo-imf.org/ieo/pages/CompletedEvaluation279.aspx

${ }^{16}$ International Labor Organization (ILO), 2017, World Social Protection Report 2017-19: Universal social protection to achieve the Sustainable Development Goals, p. 119

${ }^{17}$ Eurostat 2018: https://ec.europa.eu/eurostat/statisticsexplained/index.php/Educational_expenditure statistics

${ }^{18}$ United Nations Educational, Scientific, and Cultural Organization (UNESCO) Institute for Statistics, 'Government expenditure per student' is defined by UNESCO as the average general government expenditure (current, capital, and transfers) per student in the given level of education, expressed as a percentage of GDP per capita. The data on government expenditure per student for MCD are not available in the UN database, ${ }^{19}$ No available data on government expenditures per student in GDP per capita for Middle East and North Africa and Sub-Saharan Africa.
} 
Figure 3. Government Expenditure per Student in Levels of Education by Regions for 2017 (as \% of GDP per capita)

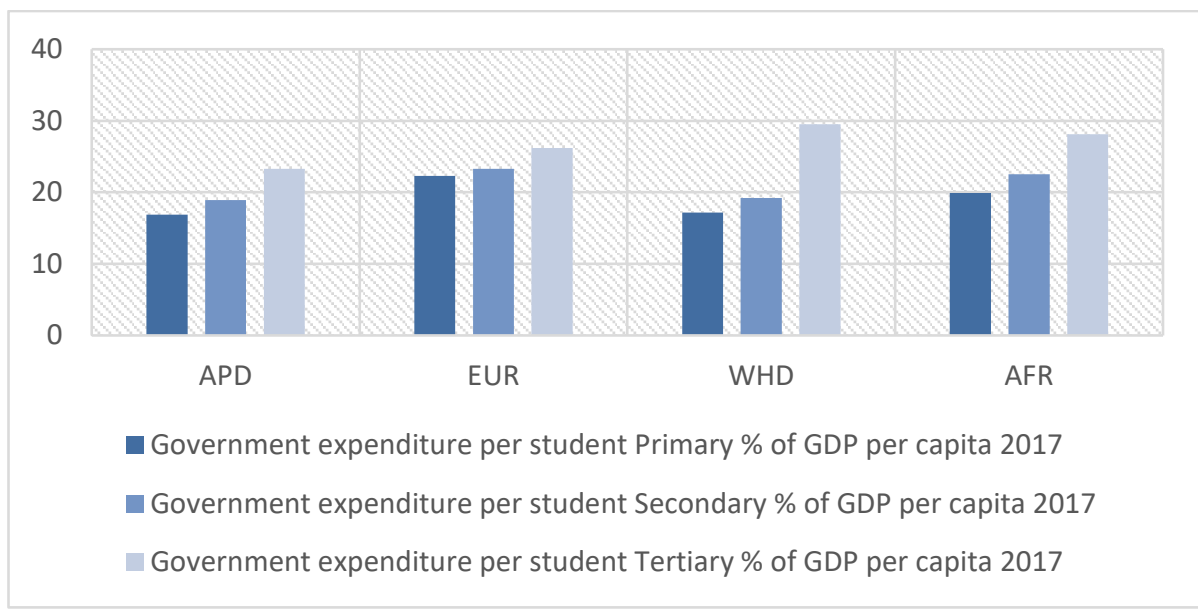

AFR (Sub-Saharan Africa); APD (Asia and Pacific); EUR (Europe), MCD (North Africa and Middle East); WHD (Western Hemisphere).

Source: United Nations Educational, Scientific, and Cultural Organization (UNESCO) Institute for Statistics, 2018.

In economies with high HDI, expected years of schooling are much higher than in other levels. As a share of their GDP, European countries have slightly higher expenditures for education as a share of GDP than other regions, however, the role of the government in providing and financing these services tends to be greater. The countries with high and very high HDI reached the level of 14-16 years, while the countries with medium and low HDI - 10 to 12 years. The mean years of schooling as a dimension of HDI is equal to 15 years, which is also a benchmark for many country groups in the sample by $2025^{20}$ (Figure 4).

Figure 4. Expected Years of Schooling and HDI for 2017

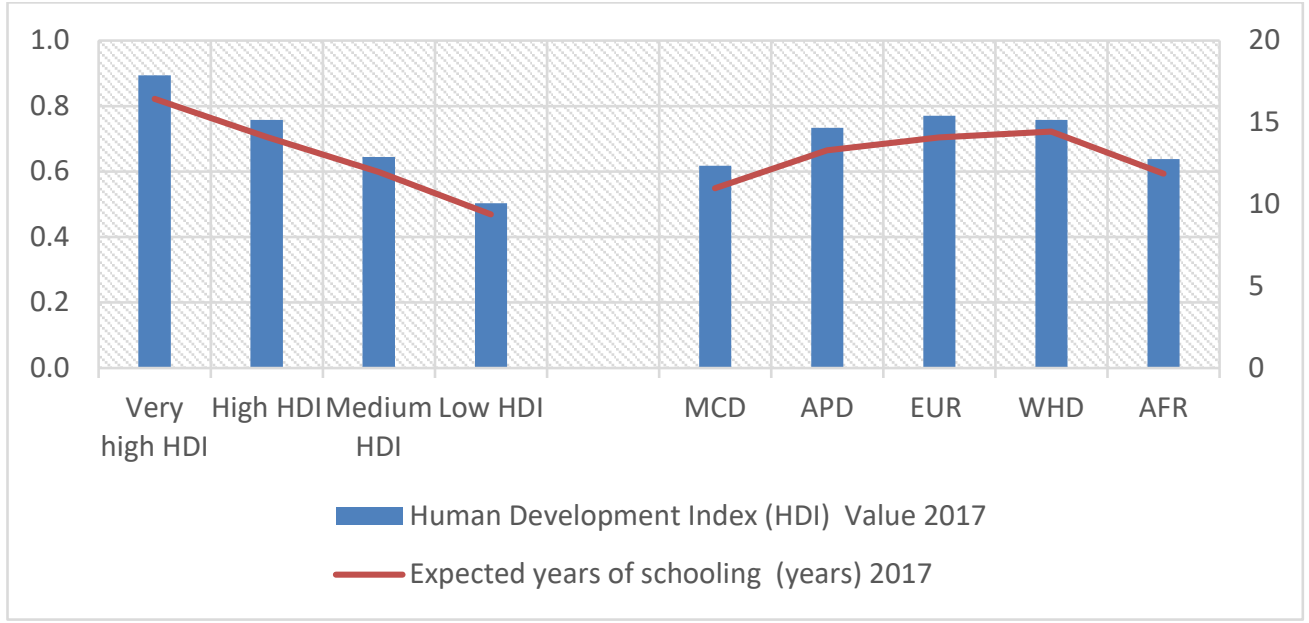

AFR (Sub-Saharan Africa); APD (Asia and Pacific); EUR (Europe), MCD (North Africa and Middle East); WHD (Western Hemisphere). Years of schooling of different regions are between 12 to 18 . HDI levels are: very high level - above 0.8, high above 0.7, medium between 0.56-0.7, and low - below 0.56 (see Appendix II). Source: Authors' estimates from UN database, 2018

${ }^{20}$ UN Human Development Report 2016, Human Development for Everyone, Technical Notes 
Nearly 50 percent of the global population lacks health coverage. The largest coverage gaps are in Sub-Saharan Africa and South Asia and Pacific, where 80 and 56 percent, respectively, of the rural population is excluded from health insurance coverage ${ }^{21}$. Europe and Central Asia have traditionally had well-developed health insurance systems. The potential economic returns from increased productivity and employment in regions should have positive effects on GNI per capita and health spending levels, and thus, closing gaps in public health coverage in developing countries.

Public expenditures for health in most developing economies is too low to be sufficiently effective to reach the life expectancy of advanced countries. Some countries in Sub-Saharan Africa and Latin America and the Caribbean spent less than 1 percent of GDP in $2016^{22}$. Thus, in many developing markets, the individuals and households may not have access to basic public healthcare services and amenities as they may not exist where they live or may be heavily distorted.

\section{More than 90 percent of the population living in low-income countries still remains} without any right to coverage by public health services ${ }^{23}$. Even people who are legally covered experience limited health benefits, high out-of-pocket payments and a lack of health workers needed to deliver services. In such circumstances, healthcare is frequently neither available nor affordable, and the cost of accessing needed services lead to poverty and lower life expectancy. Life expectancy averages 79.5 years in countries with very high HDI, compared with 60.8 in low human development countries ${ }^{24}$ (Figure 5).

Figure 5. Life Expectancy and HDI for 2017

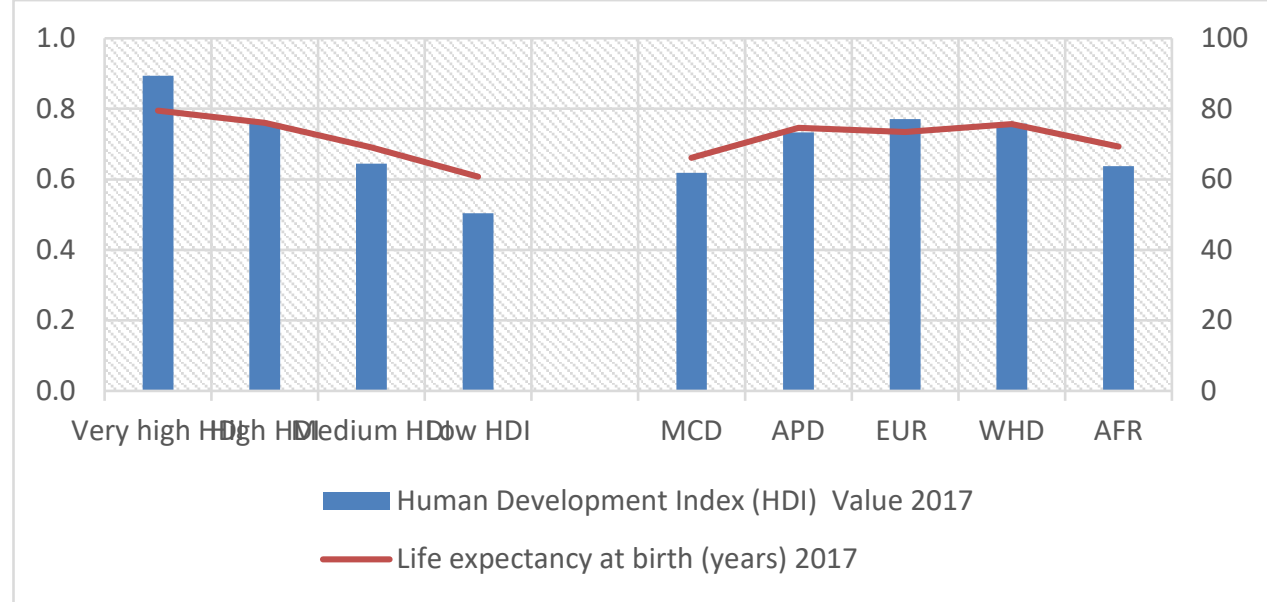

AFR (Sub-Saharan Africa); APD (Asia and Pacific); EUR (Europe), MCD (North Africa and Middle East); WHD (Western Hemisphere). Life expectancy of different regions is between 66 and 76 years. HDI levels are: very high level above 0.8, high above 0.7, medium between 0.56-0.7, and low - below 0.56 (see Appendix II).

Source: Authors' estimates from UN database, 2018

\footnotetext{
${ }^{21}$ International Labor Organization, 2017, World Social Protection Report 2017-19: Universal social protection to achieve the Sustainable Development Goals, p. 98, 104

22 GFS Database, 2018: http://data.imf.org/?sk=a0867067-d23c-4ebc-ad23d3b015045405\&sId=1409151240976

${ }^{23}$ International Labor Organization, 2017, World Social Protection Report 2017-19: Universal social protection to achieve the Sustainable Development Goals, p. 119

${ }^{24}$ Human Development Indices and Indicators: 2018 Statistical Update, 2018, United Nations Development Program, page 4
} 


\section{LITERATURE REVIEW}

One of the ultimate objectives of the SDGs is to tackle poverty and promote per capita growth and increase GNI per capita in PPP in all the regions. The literature for long-run pattern of growth has brought to the fore of importance of social sector policy, which largely focuses on enhancing in income per capita and other dimensions of human development. One strand of research looks at the models linking social spending policy with growth (Aschauer, 1989; Barro 1990, 1991; Levine and Renelt, 1992; Mittnik and Neumann, 2003), while the other research examines the relationship between social spending, outcomes and governance (Devarajan et al., 1996; Baqir 2002, De la Croix and Delavallade, 2006). Aschauer (1989) indicates that nonmilitary public capital stock is more important in determining productivity. Barro (2003) examines determinants of economic growth in a panel of countries, and cross-country panel regressions show that the difference in GDP per capita growth rates relate systematically to a set of quantifiable explanatory variables, including educational attainment and health and for given values of other variables that reflect policy, institutions and national characteristics. Mittnik and Neumann (2003)-found that the size and direction of growth effects depend on the share of public spending in GDP. Other strands of work outline the link between social spending and corruption, democracy and governance (Devarajan et al., 1996, De La Croix and Devallade, 2006,). The 2018 World Development Report states: "In general, reliable institutions that implement the rule of law, reduce corruption, and protect property rights associated with higher returns to human capital." ${ }^{25}$

The nonlinear association between government redistribution and inequality put forward by Benabou (2000) was tested by Melo and Tiongson (2003). They also conclude that when public expenditures are redistributed effectively, per capita income and social outcomes improve and living standards rises. The results for the period 1970-1998 showed that the countries where redistributive public spending is more needed were found less likely to redistribute income through public policy. Government policies that enhance income equality and educational levels, health care, and social protection, can have strongly positive impacts on well-being. Public goods and services are crucial for well-being through their more efficient allocation to households.

The analysis of Leitner and Stehrer (2016) studies the effects of public and private expenditures on public health and other social outcomes in the European Union (EU) countries. Their estimates show that higher levels of public spending and lower levels of poverty are correlated with a healthier population, higher educational levels of the youth population, higher employment rates, and reduced property and violent crime.

Increasing the level of education within a nation and across regions is a frequent focus of the research on human capital beginning with the seminal work of Becker (1964) and underscored in explanations of long-run economic growth in the United States (Barro and Lee 2015).

Although disagreement exists as to the exact means by which education raises income levels, increased education levels are thought to increase worker productivity and earnings over time. Possible dissemination channels from educational attainment to economic growth include: (1) the positive effects higher levels of education exert on the productivity of human capital (Delong et al. 2003); stimulation of entrepreneurial activity and creativity (Glaeser and Saiz,

\footnotetext{
${ }^{25}$ World Bank, 2018, World Development Report, Learning to Realize Education's Promise, Washington D.C., p. 44
} 
2004); education's role in stimulating innovation of new ideas and processes and spillovers across industries and regions (Benhabib and Speigel, 1994); and degree of worker adaptability to transfer skills and knowledge across industries (Bauer et al. 2006). Regardless of the precise source of dissemination of knowledge from the classroom to national economic accounts, the historical link from education to income remains strong in theory and empirically (Yamarik 2010). Barro (2001) examines a panel data for 100 countries and estimates that an additional year of schooling raises the growth rate on impact by 0.44 percent per year. The causality running from education spending to economic growth is also estimated by Jiranyakul and Brahmasrene (2007), Chandra and Islamia (2010), while Bose, Haque and Osborn (2003), Basu and Bhattarai (2009), Abhijeet Chandra (2010) evaluate the direction of causation running from economic growth to education expenditure.

Economic development is important for population health and living standards, but collectively provided welfare resources to compensate for market failure are crucial to the understanding of population health and well-being (Fritzell and Lundberg 2007). Long-term economic prosperity is necessary, but not sufficient condition for improvements in population health and education.

Link and Phelan (1995) stated that welfare resources are associated with 'the social determinants of health' (e.g. power, status, knowledge, work, income, social networks and general living conditions). Consequently, the concept of 'welfare resources' is linked to a spending approach through fiscal redistribution policy.

In the literature, the high social outcomes in life expectancy and educational status of the EU countries are usually explained by the EU growth model based on "the social market economy." The model has resulted in a deeper integration and quicker convergence between advanced and emerging market economies in the EU. The model was conceptually developed by Walter Euken (1942) and Alfred Mueller-Armack (1947) ${ }^{26}$ and combines the efficiency of markets with social fairness. Furthermore, Jones and Klenow (2010) propose a broad notion of the standard of living that captures not just the level of national income, but also a trade-off between leisure, consumption, and life expectancy. Perception for such a broad concept of welfare reveals that many EU countries approach levels of welfare of the United States, despite lower average EU national income.

\section{Econometric Model And DAta}

\section{A. Econometric Model and Methodology}

Building on past empirical studies about the redistributive function of fiscal policy and its impact on social outcomes, we used panel regressions to assess the effects of public social expenditures on the indicators of the HDI dimensions. We utilized several steps to build the model for examining the causal effect between public social spending and alternative dependent variables.

Following the methodology introduced by Acemoglu et al. (2008), we employ an OLS fixed effects panel distributed lag equation applying lagged dependent variable and lagged explanatory variables in equation (1).

$\mathrm{y}_{\mathrm{it}}=\mathrm{c}+\alpha \mathrm{y}_{\mathrm{it}}-1+\beta \mathrm{x}_{\mathrm{it}-1}+\mu \mathrm{Z}_{\mathrm{it}-1}+\delta_{\mathrm{i}}+\gamma_{\mathrm{t}}+\varepsilon_{\mathrm{it}}(1)$

${ }^{26}$ World Bank, 2012, Golden Growth - restoring the luster of the European economic model, Washington, DC, page 43 
where c parameter represents the overall constant in the model, $\alpha$ represents time effects of vector $y_{i t}-1$, lagged dependent variable of $y_{i t}$, which is included to capture persistence in dependent variables and potentially the tendency to return to some equilibrium value for the country. The main variable of interest is $\mathrm{x}_{\mathrm{it}}-1$, lagged value of explanatory variables ( $\mathrm{k}$-vector of regressors). The $\beta$ represents effects of explanatory variables on the dependent variable of all countries, while $\mu$ effects of all other potential covariates included in the vector $Z_{\mathrm{it}-1}$. The $\delta_{\mathrm{i}}$ denotes a full set of country dummies and $\gamma_{t}$ represents full set of time effects that capture common shocks to the dependent variables of all countries; $\varepsilon_{\mathrm{it}}$ is an error term, capturing all other omitted factors.

We applied several strategies to deal with the potential for endogeneity, which may be due to omitted variables in the equation or reverse causality from the dependent to explanatory variables. The first strategy for reducing the endogeneity problem and reverse causality, also applied by Acemoglu et al. (2008), is to enter the explanatory variable(s) and dependent variable with lag. The reasoning is that causality can only flow forward in time. If there is feedback from dependent variable to an explanatory variable, this cannot take the form of an effect of $y(t)$ on $x(t-1)$. Furthermore, changes in the explanatory variables are not expected to impact the dependent variable immediately, providing theoretical support for this lagged specification.

The second strategy is to control for factors that simultaneously affect both variables. Similar to Acemoglu et al. (2008), we used fixed effects as a strategy to control for country-specific factors and time-specific events affecting both public social spending and dependent variables. With the fixed effects we solve the major source of potential bias in the regressions, which can arise from the omission of country specific, historical or structural factors influencing both social spending and the HDI components. Thus, we control for these omitted determinates with time and cross section effects. The alternative panel model using random effects faces the danger of correlations between regressors and the error components, and we employ the Hausman test for endogeneity to choose between the fixed effects or random effects models.

The third strategy is to use the method of instrumental variables to address endogeneity. Fixed effects are not always a panacea for omitted variables, and to prove the robustness of our econometric results we also consider various control variables in addition to the fixed effects.

Additionally, a set of procedures within the generalized method of movements (GMM) framework provides a methodology for defining instruments that are appropriate for dynamic panel models, i.e. those with a lagged dependent variable. Following Acemoglu et al. (2008), we employ the (GMM) estimator of Arellano and Bond (1991). They extended the methodology of Anderson and Hsiao (1982) ${ }^{27}$, which is to time difference equation (2). Thus, we obtain:

$\Delta \mathrm{y}_{\mathrm{it}}=\mathrm{c}+\alpha \Delta \mathrm{y}_{\mathrm{it}}-1+\beta \Delta \mathrm{x}_{\mathrm{it}-1}+\mu \Delta \mathrm{Z}_{\mathrm{it}-1}+\Delta \gamma_{\mathrm{t}}+\Delta \varepsilon_{\mathrm{it}}(2)$

where the fixed country effects are removed by time differencing. The $y_{i t}-2$ is uncorrelated with $\Delta \varepsilon_{\mathrm{it}}$, so can be used as an instrument for $\Delta \mathrm{y}_{\mathrm{it}-1}$ to obtain consistent estimates, and similarly $\mathrm{x}_{\mathrm{it}-2}$ is used as an instrument for $\Delta \mathrm{x}_{\mathrm{it}-1}$, and $\mathrm{Z}_{\mathrm{it}-2}$ for $\Delta \mathrm{Z}_{\mathrm{it}-1}$.

\footnotetext{
${ }^{27}$ Anderson and Hsiao (1982) clustered standard errors, while the GMM of Arellano and Bond (1991) with robust standard errors.
} 
Applying the panel cross-section heteroskedasticity test we ensured the consistency of the OLS estimator in the time series regression model. We solved heteroskedasticity in the specifications using the method White cross-section for panel data. We control for Durbin-Watson statistics to ensure that it is close to the value of 2 , which suggest that there is no autocorrelation ${ }^{28}$.

\section{B. Dependent and Explanatory variables}

We build panel data on dependent variables for the period 1995-2016: (i) GNI per capita (in 2011 PPPs in \$); (ii) expected years in schooling ${ }^{29}$; and (iii) life expectancy from the United Nations' Global Indicator Database ${ }^{30}$, including the UN HDI data and the World Bank's (WB) World Development Indicators (WDI) ${ }^{31}$ (Table 1).

We used for our analysis panel data on explanatory variables: (i) COFOG data ${ }^{32}$ on public social spending for education, healthcare and social spending as percent of GDP for the period 1995-2016 reported in the GFSY database for 68 countries (Appendix 1).

The methodology behind the data, and the data tests are presented in more detail in Appendix II.

\section{Control variables}

The justification for the use of population and population growth, terms of trade is to control for country size, openness and income respectively. The literature on per capita growth (Aschauer, 1989; Barro 1990, 1991; Levine and Renelt, 1992; Mittnik and Neumann, 2003) generally employs the investment ratio to isolate the effect of the saving rate on growth. The terms of trade variable measures the effect of changes in international prices on the income position of domestic residents. This captures the idea that an economy with a high degree of openness has the advantage of increasing the volume of commerce, which can raise per capita incomes under conditions of favorable terms of trade. Inflation, an additional control variable, corrodes the purchasing power of economic agents, but on the other hand an increase in inflation promotes an increase in output taking into consideration of Phillip's curve trade-off between inflation and unemployment rates. Investment rates (gross capital formation as percent of GDP) and inflation (measured by CPI) are based on the System of National Accounts (SNA) methodology. The investment ratio (gross capital formation as percent of GDP), inflation measured by CPI, terms of trade (percentage ratio of the export unit value indexes to the import unit value indexes) ${ }^{33}$,

\footnotetext{
28 There are several limitations of this test and we tried to implement Cross-section dependence tests and Arrelano-Bond serial correlation test, which however are not applicable for our estimating equations, because it is available only for panel GMM equations estimated by first differences.

${ }^{29}$ Expected years of schooling is operationally defined as "Number of years of schooling that a child of school entrance age can expect to receive if prevailing patterns of age-specific enrolment rates persist throughout the child's life." UN Human Development Report http://hdr.undp.org/en/content/expected-years-schoolingchildren-years

${ }^{30}$ United Nations' Database: http://data.un.org/Explorer.aspx?d=WDI; http://hdr.undp.org/en/data\#

${ }^{31}$ United Nations' HDI database: http://hdr.undp.org/en/data\#

32 IMF database: https://www.imf.org/en/Data

${ }^{33}$ Net barter terms of trade index is calculated as the percentage ratio of the export unit value indexes to the import unit value indexes, measured relative to the base year 2000. Unit value indexes are based on data reported by countries that demonstrate consistency under UNCTAD quality controls, supplemented by UNCTAD's estimates using the previous year's trade values at the Standard International Trade Classification three-digit level as weights. To improve data coverage, especially for the latest periods, UNCTAD constructs a set of average prices indexes at the three-digit product classification of the Standard International Trade Classification revision 3 using UNCTAD's Commodity Price Statistics, interna-tional and national sources,
} 
population and population growth; literacy rate (percent of total population), Gini index ${ }^{34}$, are used in the study as one set of control variables. GNI per capita is uses as a control variable for life expectancy.

The World Government Indicators (WGI) control for other variables that reflect policies, institutions and national characteristics, and they are used in the study as a second set of control variables. The assumption is that an improvement in the WGI implies better business environment, and therefore an incentive for higher investment and GNI per capita. The estimates of governance (ranges from approximately -2.5 (weak) to 2.5 (strong) governance performance). The WGI project reports aggregate and individual governance indicators for over 200 countries and territories over the period 1996-to present, for six dimensions of governance. These aggregate indicators combine the views of a large number of enterprises, citizen and expert survey respondents in industrial and developing countries. They are based on over 30 individual data sources produced by a variety of survey institutes, think tanks, non-governmental organizations, international organizations, and private sector firms. The WGI captures perceptions of the extent to which country citizens are able to participate in selecting their government (voice and accountability); the likelihood that the government will be destabilized (political stability and absence of control); the quality of public services (government effectiveness); the extent to which agents have confidence in the abide by the rules of society (rule of law), the ability of the government to formulate and implement sound policies and regulations (regulatory quality), and the extent to which public power is exercised to private gain (control of corruption).

Total population (in logs), population growth, literacy rate (in logs), Gini index, terms of trade, inflation (in logs), investment rates are from the IMF's World Economic Outlook (WEO) and the WB's Open Data database. The data on voice and accountability, government effectiveness, political stability and no violence, rule of law, regulatory quality, and control of corruption are from the WB's WGI database ${ }^{35}$ (Table 1).

Table 1. Summary Statistics

\begin{tabular}{|l|l|l|l|l|l|l|l|}
\hline \multicolumn{1}{|c|}{ Variable } & Mean & Median & Maximum & Minimum & $\begin{array}{c}\text { Std. } \\
\text { Dev. }\end{array}$ & Observations & Source \\
\hline \begin{tabular}{l} 
Dependent variable \\
\hline $\begin{array}{l}\text { GNI per capita } \\
\text { in 2011 PPPs } \\
\text { (in USD, logs) }\end{array}$
\end{tabular} & 21110 & 17769.7 & 67031.5 & 7164.0 & 15492.6 & 1313 & WDI Database \\
\hline $\begin{array}{l}\text { Expected year } \\
\text { in schooling }\end{array}$ & 13.6 & 13.7 & 20.7 & 3.9 & 2.9 & 1428 & $\begin{array}{l}\text { UN HDI } \\
\text { Database }\end{array}$ \\
\hline $\begin{array}{l}\text { Life } \\
\text { expectancy }\end{array}$ & 72.5 & 73.7 & 83.7 & 42.1 & 7.6 & 1428 & $\begin{array}{l}\text { UN HDI } \\
\text { Database }\end{array}$ \\
\hline $\begin{array}{l}\text { Explanatory variables } \\
\text { Public } \\
\text { educational } \\
\text { expenditures } \\
\text { as \% of GDP }\end{array}$ & 4.7 & 4.8 & 9.2 & 921.1 & 1.6 & 1149 & $\begin{array}{l}\text { IMF GFS } \\
\text { Database }\end{array}$ \\
\hline
\end{tabular}

and UNCTAD secretariat estimates and calculates unit value indexes at the country level using the current year's trade values as weights.

34 The World Bank's methodology for Gini index used in the study is presented in Appendix II).

35 https://datacatalog.worldbank.org/dataset/worldwide-governance-indicators 


\begin{tabular}{|c|c|c|c|c|c|c|c|}
\hline Variable & Mean & Median & Maximum & Minimum & $\begin{array}{l}\text { Std. } \\
\text { Dev. }\end{array}$ & Observations & Source \\
\hline $\begin{array}{l}\text { Public health } \\
\text { expenditures } \\
\text { as \% of GDP }\end{array}$ & 4.4 & 4.2 & 28.1 & 0.04 & 3.4 & 1142 & $\begin{array}{l}\text { IMF GFS } \\
\text { Database }\end{array}$ \\
\hline $\begin{array}{l}\text { Public social } \\
\text { protection as } \\
\% \text { of GDP }\end{array}$ & 10.1 & 10.7 & 25.6 & 0 & 7.3 & 1140 & $\begin{array}{l}\text { IMF GFS } \\
\text { Database }\end{array}$ \\
\hline \multicolumn{8}{|c|}{ Control variables } \\
\hline Gini index & 36.0 & 34.25 & 43.45 & 32.29 & 3.4 & 1518 & WB WDI \\
\hline $\begin{array}{l}\text { GNI per capita } \\
\text { in } 2011 \text { PPPs } \\
\text { (in USD, logs) }\end{array}$ & 21110 & 17769.7 & 67031.5 & 7164.0 & 15492.6 & 1313 & WB WDI \\
\hline Literacy rate & 89.7 & 89.9 & 91.8 & 84.6 & 1.5 & 1518 & WB WDI \\
\hline $\begin{array}{l}\text { Total } \\
\text { population (in } \\
\operatorname{logs} \text { ) }\end{array}$ & 18.08 & 18.08 & 18.18 & 17.97 & 0.06 & 1518 & WB WDI \\
\hline $\begin{array}{l}\text { Population } \\
\text { growth }\end{array}$ & 0.89 & 0.90 & 1.02 & 0.76 & 0.06 & 1449 & WB WDI \\
\hline Terms of trade & 103.8 & 98.8 & 253.3 & 44.32 & 26.87 & 1274 & WB WDI \\
\hline $\begin{array}{l}\text { Inflation (in } \\
\text { logs) }\end{array}$ & 4.72 & 4.52 & 18.03 & -5.9 & 1.74 & 1473 & IMF WEO \\
\hline $\begin{array}{l}\text { Investment } \\
\text { rates }\end{array}$ & 21.95 & 22.20 & 68.94 & 0.0 & 0.10 & 1527 & IMF WEO \\
\hline $\begin{array}{l}\text { Voice and } \\
\text { Accountability }\end{array}$ & 0.40 & 0.59 & 1.8 & -1.76 & 0.92 & 1564 & WB WGI \\
\hline $\begin{array}{l}\text { Political } \\
\text { Stability and } \\
\text { Absence of } \\
\text { Violence }\end{array}$ & 0.22 & 0.44 & 1.76 & -2.81 & 0.92 & 1541 & WB WGI \\
\hline $\begin{array}{l}\text { Government } \\
\text { effectiveness }\end{array}$ & 0.51 & 0.43 & 2.35 & -1.46 & 0.92 & 1518 & WB WGI \\
\hline $\begin{array}{l}\text { Regulatory } \\
\text { Quality }\end{array}$ & 0.51 & 0.56 & 2.09 & -1.79 & 0.86 & 1564 & WB WGI \\
\hline Rule of Law & 0.44 & 0.40 & 2.10 & -1.7 & 0.97 & 1564 & WB WGI \\
\hline $\begin{array}{l}\text { Control of } \\
\text { Corruption }\end{array}$ & 0.41 & 0.31 & 2.46 & -1.52 & 1.07 & 1564 & WB WGI \\
\hline
\end{tabular}

\section{BASIC ECONOMETRIC RESUltS}

This section presents the basic econometric estimates of the impact of social spending on the various dependent variables. Several specifications of equation (1) are estimated for each indicator of the HDI dimensions: GNI per capita (in logs, in 2011 PPPs in \$), expected years in schooling (in logs), and life expectancy (in logs). The Hausman test for endogeneity is employed to decide which of either fixed effect model or random effects model is appropriate. 


\section{A. GNI per Capita and Public Social Expenditures}

We apply the first strategy for reducing the endogeneity problem and reverse causality, following by Acemoglu et al. (2008). We enter the explanatory variable(s) and dependent variable with lag in equation (1) ${ }^{36}$. As explained in the methodology, the reasoning is that causality can only flow forward in time. If there is feedback from dependent variable to an explanatory variable, this cannot take the form of an effect of $y(t)$ on $x(t-1)$. Furthermore, changes in the explanatory variables are not expected to impact the dependent variable immediately, providing theoretical support for this lagged specification. The basic econometric results for GNI per capita and different public social spending (educational, health and social protection) are reported in

Table 2.

Applying the Hausman test we choose the fixed effects model. The p value of the Hausman test of the random effects model is 0 , suggesting that the results are statistically significant. Thus, we reject Ho that the error term is not correlated with the explanatory variables, which means that the fixed effects model is appropriate. The results show that a 1 percent difference in public educational expenditure leads to a 0.020 (OLS) percent difference in the average GNI per capita in the short run and larger in long run. The estimated coefficients for health spending are statistically significant, but the coefficient of health spending is negative, which means that it is not meaningful. The coefficient of social protection of 0.0002 is small in magnitude, but statistically significant. To address potential endogeneity, the results need further examination and we include additional controls using method of instrumental variables and GMM estimator in the new specifications in Section VI.

Table 2. Basic Regression Results for GNI per Capita and Public Educational Spending

\begin{tabular}{|l|c|c|c|}
\hline & \multicolumn{3}{|c|}{ Dependent variable } \\
& GNI per capita in 2011 PPPs \$ prices (in logs) \\
\hline \multicolumn{1}{|c|}{ Explanatory variable } & $\begin{array}{c}\text { Fixed effects } \\
\text { OLS }\end{array}$ & $\begin{array}{c}\text { Fixed effects } \\
\text { OLS }\end{array}$ & $\begin{array}{c}\text { Fixed effects } \\
\text { OLS }\end{array}$ \\
\hline \multicolumn{1}{|c|}{ Specifications } & $(1)$ & $(2)$ & $(3)$ \\
\hline Constant & $0.6755^{* * *}$ & $0.7744^{* * *}$ & $0.8341^{* * *}$ \\
& $(0.1477)$ & $(0.1319)$ & $(0.1333)$ \\
Public education expenditures & $0.0204^{* * *}$ & & \\
as \% of GDP (in logs, lagged) & $(0.0078)$ & & \\
$\begin{array}{l}\text { Public health expenditures as } \\
\% \text { of GDP (in logs, lagged) }\end{array}$ & & -0.0036 & \\
$\begin{array}{l}\text { Public social protection } \\
\text { expenditures as \% of GDP (in }\end{array}$ & & $(0.0029)$ & \\
logs, lagged) & & & $0.0027^{* *}$ \\
$\begin{array}{l}\text { GNI per capita in 2011 PPPs } \$ \\
\text { prices (in logs, lagged as an } \\
\text { explanatory variable) }\end{array}$ & $0.9295^{* * *}$ & $0.9227^{* * *}$ & $0.9158^{* * *}$ \\
\hline
\end{tabular}

\footnotetext{
${ }^{36}$ The estimated coefficients in the specifications without lagged dependent variables (not reported in the paper) are highly sensitive to the inclusion of country fixed effects. The specifications report results that do not control for country specific heterogeneity, and therefore these estimates are not meaningful - they are biased.
} 


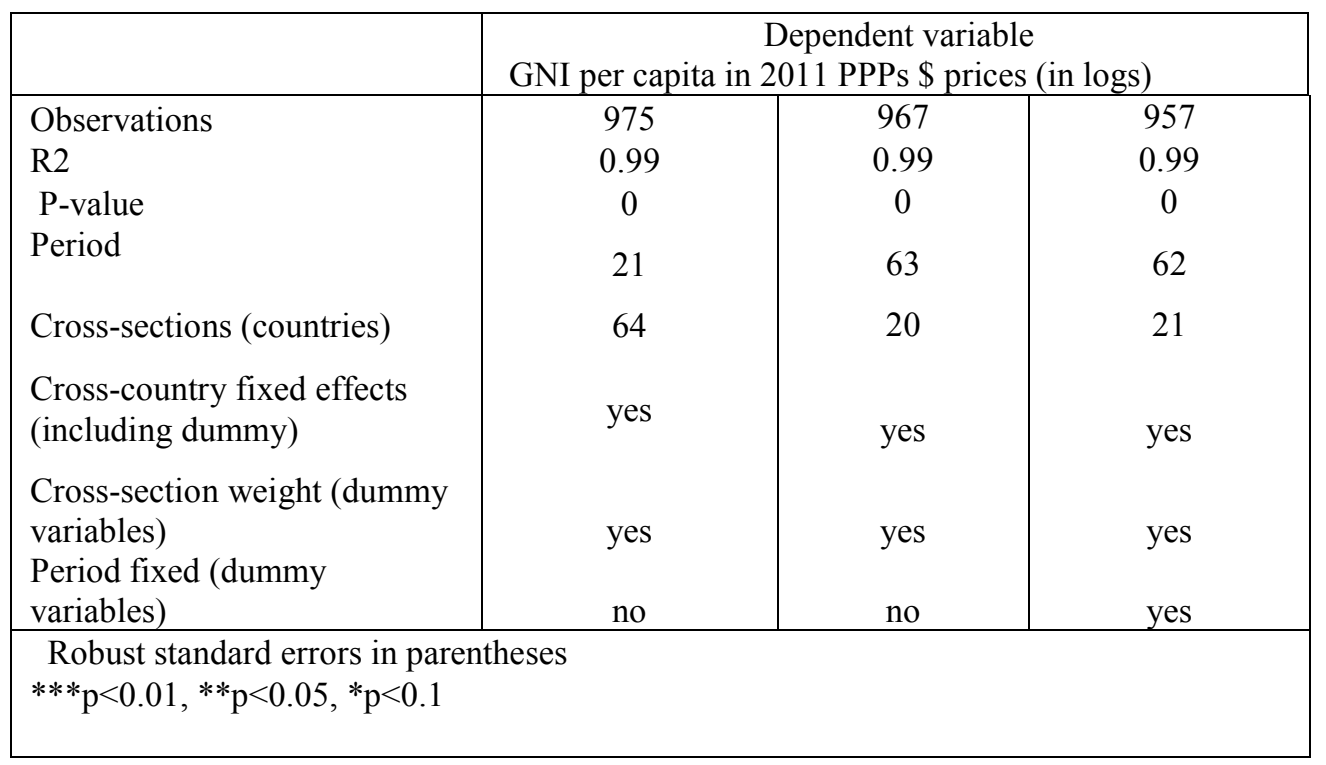

\section{B. Expected Years of Schooling and Public Educational Spending}

We apply the first strategy for reducing the endogeneity problem and reverse causality, following by Acemoglu et al. (2008) in two steps. First, we examine the specifications using equation

(1) with lagged explanatory variables in a static model and fixed effects model. Then, we add lagged dependent variable in the fixed effects model and compare the long-term effects with the static model without lagged variable ${ }^{37}$. The results are reported in Table 3.

Investments in education by convention should have positive effects on educational status of the population and thus on employment and productivity levels. In the specification (1) we apply static model without fixed effects and the results show that a 1 percent increase of public educational spending in the first specification with OLS imply 0.233 percent difference in the expected years of schooling. The response coefficients in the specifications (2) to (3) with fixed effects show that a 1 percent increase in public educational spending leads to 0.130 and 0.193 percent increase in expected years of schooling depending on the fixed effects. The p-value of the Hausman test of the random effects model of the same specification is 0 , suggesting that the fixed effects model is appropriate. Applying a fixed effects model with a lag dependent variable reduces the coefficients in the specification (4) to 0.014 in short-run and 0.130 in the long run ${ }^{38}$, which is comparable with the coefficients 0.130 and 0.193 in the fixed effects static model without lagged dependent variable. To address potential endogeneity, however, the results need further investigation and we include further controls using method of instrumental variables and GMM estimator in the new specifications in Section VI.

\footnotetext{
${ }^{37}$ The long run coefficient in the model with lagged dependent variable is the value that is relevant for comparison with the coefficient in the static model without lagged dependent.

${ }^{38}$ It should be noted that for the equations with a lagged dependent variable, the coefficient (call it $\beta$ ) on an explanatory variable gives only the short run effect. The long run effect is given by $\beta /(1-\alpha)$ where $\alpha$ is the coefficient on the lagged dependent variable (Acemoglu et al. 2008). In some of the equations the $\alpha$ coefficient is quite close to 1 , which makes the long run effect larger.
} 
Table 3. Basic Regression Results for Expected Years of Schooling

\begin{tabular}{|c|c|c|c|c|}
\hline \multirow[b]{2}{*}{ Explanatory variable } & \multicolumn{4}{|c|}{$\begin{array}{c}\text { Dependent variable } \\
\text { Expected years of schooling (in logs) }\end{array}$} \\
\hline & OLS & $\begin{array}{l}\text { Fixed } \\
\text { effects OLS }\end{array}$ & $\begin{array}{c}\text { Fixed } \\
\text { effects } \\
\text { OLS }\end{array}$ & $\begin{array}{c}\text { Fixed effects } \\
\text { OLS }\end{array}$ \\
\hline & (1) & $(2)$ & (3) & (4) \\
\hline $\begin{array}{l}\text { Public education expenditures as \% of GDP } \\
\text { (in logs, lagged) } \\
\text { Expected years of schooling (in logs, } \\
\text { lagged) }\end{array}$ & $\begin{array}{l}0.2332 * * \\
(0.0088)\end{array}$ & $\begin{array}{c}0.1307 * * \\
(0.0089)\end{array}$ & $\begin{array}{l}0.1934^{*} \\
(0.0167)\end{array}$ & $\begin{array}{l}0.0141 * * * \\
(0.0027) \\
0.8928 * * * \\
(0.8928)\end{array}$ \\
\hline Constant & $\begin{array}{l}2.2899 \\
(0.0137)\end{array}$ & $\begin{array}{c}2.4377 \\
(0.0129)\end{array}$ & $\begin{array}{c}2.3472 \\
(0.0242)\end{array}$ & $\begin{array}{l}0.2499 * * * \\
(0.0201)\end{array}$ \\
\hline Observations & 1084 & 1184 & 1084 & 1084 \\
\hline $\mathrm{R} 2$ & 0.39 & 0.96 & 0.90 & 0.99 \\
\hline P-value & 0 & 0 & 0 & 0 \\
\hline $\begin{array}{l}\text { Cross-country fixed effects (dummy } \\
\text { variables) }\end{array}$ & no & yes & yes & yes \\
\hline Cross-section weights (dummy variables) & no & yes & no & yes \\
\hline $\begin{array}{l}\text { Robust standard errors in parentheses } \\
* * * \mathrm{p}<0.01, * * \mathrm{p}<0.05, * \mathrm{p}<0.1\end{array}$ & & & & \\
\hline
\end{tabular}

\section{Life Expectancy and Public Health Spending}

We apply the first strategy for reducing the endogeneity problem and reverse causality, following by Acemoglu et al. (2008) in two steps, similar to the approach applied for expected years of schooling. The results are reported in Table 4.

The output of the health system is expressed either by longevity indicators, such as life expectancy or mortality rates. The countries with higher income per capita levels are expected to have higher life expectancy. In the OLS static fixed effects model without lagged dependent variable the effect of a 1 percent public health expenditure (lagged) imply a percentage increase in life expectancy of 0.017 . The p-value of the Hausman test of the random effects model of the same specification is 0 , suggesting that the fixed effects model is appropriate. The coefficient is reduced to 0.0005 in shortterm, in the specification with lagged explanatory and dependent variables, and the long-run effect ${ }^{39}$ of 0.020 is comparable with the coefficient of 0.017 in the fixed effect static model and the estimates of Leitner and Stehler (2016) for the EU countries. The estimations for short-run effects are consistent with the estimations of Jaba et al. (2014) for groups of countries defined by income level for the period 1995-2010, which depict the effects of 0.006 for low income countries and 0.004 for upper middle-income countries. We include further controls using method of instrumental variables and GMM estimator in the new specifications in Section VI to address potential endogeneity.

\footnotetext{
${ }^{39}$ The long-run effect is given by $\beta /(1-\alpha)$ where $\alpha$ is the coefficient on the lagged dependent variable (Acemoglu et al. 2008).
} 
Table 4. Basic Regression Results for Life Expectancy

\begin{tabular}{|c|c|c|c|c|}
\hline \multirow[b]{2}{*}{ Explanatory variable } & \multicolumn{4}{|c|}{$\begin{array}{c}\text { Dependent variable } \\
\text { Life expectancy (in logs) }\end{array}$} \\
\hline & $\begin{array}{l}\text { OLS } \\
\text { (1) }\end{array}$ & $\begin{array}{c}\text { Fixed effects } \\
\text { OLS } \\
\text { (2) }\end{array}$ & $\begin{array}{l}\text { Fixed effects } \\
\text { OLS } \\
\text { (3) }\end{array}$ & $\begin{array}{l}\text { Fixed effects } \\
\text { OLS } \\
\text { (4) }\end{array}$ \\
\hline $\begin{array}{l}\text { Public health expenditures as \% of } \\
\text { GDP (in logs, lagged) } \\
\text { Life expectancy (in logs, lagged) } \\
\text { Constant } \\
\text { Observation } \\
\text { R2 } \\
\text { P-value } \\
\text { Cross-sections } \\
\text { Periods } \\
\text { Cross-country fixed effects (including } \\
\text { dummy) } \\
\text { Cross-country weight (dummy } \\
\text { variables) }\end{array}$ & $\begin{array}{c}4.2347 \\
(0.0044) \\
1081 \\
0.19 \\
0 \\
67 \\
20 \\
\\
\text { no } \\
\text { no }\end{array}$ & $\begin{array}{c}4.2698 \\
(0.0017) \\
961 \\
0.63 \\
0 \\
67 \\
20 \\
\text { yes }\end{array}$ & $\begin{array}{c}4.2698 \\
(0.0017) \\
1081 \\
0.97 \\
0 \\
67 \\
20 \\
\text { yes } \\
\\
\text { yes }\end{array}$ & $\begin{array}{c}0.0005^{* * *} \\
(0.0001) \\
0.9752^{* * *} \\
(0.0022) \\
0.1092^{* * *} \\
(0.0096) \\
1081 \\
0.99 \\
0 \\
67 \\
20 \\
\text { yes }\end{array}$ \\
\hline $\begin{array}{l}\text { Robust standard errors in parentheses } \\
{ }^{* * *} \mathrm{p}<0.01,{ }^{* *} \mathrm{p}<0.05,{ }^{*} \mathrm{p}<0.1\end{array}$ & & & & \\
\hline
\end{tabular}

\section{RobUSTNESS}

\section{A. GNI per Capita and Public Social Expenditures}

The estimation of causal effects requires exogenous sources of variation as fixed effect estimators do not necessarily identify such effects of public spending on GNI per capita. To check the robustness of our basic results we include public spending on education, health and social protection in one specification of equation (1) adding the following control variables in the equation (1): (i) population growth, inflation in logs, investment, terms of trade; and (ii) WGI - voice and accountability, political stability and no violence, government effectiveness, rule of law, regulatory quality, and control of corruption. We also apply the GMM estimator using equation (2). The results are reported in Table 5.

The effect of educational spending on GNI per capita changes from 0.020 to 0.023 in specification (2) when the variables of public expenditures for health and social protections are included in the equation (1). The coefficients of both health $(-0.010)$ and social protections (0.002) in the specification (2) are now statistically significant, but the negative sign of health means again that the coefficient of health is not meaningful.

The GMM estimator of 0.036 in specification (3) with instrumental variables second lag of the dependent and explanatory variable is similar to the coefficient of 0.020 in the specification (1) with fixed effects and lagged dependent and explanatory variable. Thus, a 1 percent difference in public educational spending leads to an increase in GNI per capita of 0.018 (OLS) percent. This is consistent with the findings of causality running from public educational spending to 
economic growth in the research of Jiranyakul and Brahmasrene (2007), Chandra and Islamia (2010).

The specifications (4) and (5) with instrumental variables population growth, inflation, investment rates, terms of trade do not reduce the estimated effect of educational spending and are 0.017 and 0.018 , respectively. The effects of social protection of 0.002 on GNI per capita remain the same. Controlling for other factors and introducing the voice and accountability, political stability and no violence, government effectiveness, rule of law, regulatory quality, and control of corruption in the model in specifications (6) and (11) does not change the effect of the educational spending on GNI per capita, which remains statistically significant.

Table 5. Robustness Checks for GNI and Public Social Spending

\begin{tabular}{|c|c|c|c|}
\hline \multirow[b]{2}{*}{ Explanatory variable } & \multicolumn{3}{|c|}{$\begin{array}{l}\text { Dependent variable GNI per capita } \\
\text { (in logs) }\end{array}$} \\
\hline & $\begin{array}{c}\text { Fixed effects OLS } \\
\text { Basic results }\end{array}$ & Fixed effects OLS & GMM estimator \\
\hline Specification & (1) & (2) & (3) \\
\hline Constant & $\begin{array}{l}0.6755^{\star * *} \\
(0.1477)\end{array}$ & $\begin{array}{l}0.7445^{*} \\
(0.0692)\end{array}$ & $\begin{array}{c}0.8482 * * * \\
(0.1535)\end{array}$ \\
\hline $\begin{array}{l}\text { Public education } \\
\text { expenditures as \% of GDP (in } \\
\text { logs, lagged) }\end{array}$ & $\begin{array}{l}0.0204^{\star * *} \\
(0.0078)\end{array}$ & $\begin{array}{l}0.0233 * * * \\
(0.0080)\end{array}$ & $\begin{array}{l}0.0364 * * \\
(0.0180)\end{array}$ \\
\hline $\begin{array}{l}\text { GNI per capita in } 2011 \text { PPPs } \\
\$ \text { prices (in logs, lagged as an } \\
\text { explanatory variable) }\end{array}$ & $\begin{array}{l}0.9295^{\star * *} \\
(0.0158)\end{array}$ & $\begin{array}{l}0.9229 * * * \\
(0.0070)\end{array}$ & $\begin{array}{l}0.9095 * * \\
(0.0181)\end{array}$ \\
\hline $\begin{array}{l}\text { Public health expenditures as } \\
\% \text { of GDP (in logs, lagged) } \\
\text { Public social protection } \\
\text { expenditures as \% of GDP (in } \\
\text { logs, lagged) }\end{array}$ & & $\begin{array}{c}-0.0109 * * \\
(0.0044) \\
0.0028 * \\
(0.0016)\end{array}$ & \\
\hline Observations & 975 & 903 & 904 \\
\hline $\mathrm{R} 2$ & 0.99 & 0.99 & 0.98 \\
\hline P-value & 0 & 0 & 0 \\
\hline Period & 20 & 20 & 19 \\
\hline Cross-sections & 64 & 60 & 64 \\
\hline $\begin{array}{l}\text { Cross-country fixed effects } \\
\text { (including dummy) }\end{array}$ & yes & yes & yes \\
\hline Cross-country weights & yes & yes & yes \\
\hline $\begin{array}{l}\text { Period fixed (dummy } \\
\text { variables } \\
\text { Instrument rank }\end{array}$ & no & no & $\begin{array}{l}\text { no } \\
66\end{array}$ \\
\hline $\begin{array}{l}\text { Robust standard errors in parenth } \\
* * * p<0.01, * * p<0.05, * p<0.1\end{array}$ & & & \\
\hline
\end{tabular}


Table 5. Robustness Checks for GNI and Public Social Spending (continued)

\begin{tabular}{|c|c|c|c|c|}
\hline \multirow[b]{2}{*}{ Explanatory variable } & \multicolumn{4}{|c|}{$\begin{array}{l}\text { Dependent variable GNI per capita } \\
\text { (in logs) }\end{array}$} \\
\hline & $\begin{array}{l}\text { Fixed effects } \\
\text { OLS }\end{array}$ & & $\begin{array}{l}\text { Fixed effects } \\
\quad \text { OLS }\end{array}$ & $\begin{array}{l}\text { Fixed effects } \\
\text { OLS }\end{array}$ \\
\hline Specifications & (4) & (5) & (6) & (7) \\
\hline Constant & $\begin{array}{c}0.6645^{* * *} \\
(0.0718)\end{array}$ & $\begin{array}{c}0.6375^{* * * *} \\
(0.0859)\end{array}$ & $\begin{array}{l}0.8235^{* * *} \\
(0.1161)\end{array}$ & $\begin{array}{l}0.7062^{* * *} \\
(0.1050)\end{array}$ \\
\hline $\begin{array}{l}\text { Public education expenditures as } \\
\% \text { of GDP (in logs, lagged) }\end{array}$ & $\begin{array}{l}0.0175^{* *} \\
(0.0076)\end{array}$ & $\begin{array}{c}0.0189 * * \\
(0.0075)\end{array}$ & $\begin{array}{l}0.0188^{* *} \\
(0.0075)\end{array}$ & $\begin{array}{c}0.0213 * * * \\
(0.0076)\end{array}$ \\
\hline $\begin{array}{l}\text { GNI per capita in } 2011 \text { PPPs } \$ \\
\text { prices (in logs, lagged as an }\end{array}$ & $0.9264 * * *$ & $0.9513 * * *$ & $0.9391 * * *$ & $0.9485^{* * * *}$ \\
\hline $\begin{array}{l}\text { Public health expenditures as \% } \\
\text { of GDP (in logs, lagged) }\end{array}$ & $\begin{array}{c}-0.0097 * * \\
(0.0042)\end{array}$ & $\begin{array}{l}-0.0071 \\
(0.0043)\end{array}$ & $\begin{array}{l}-0.0071^{*} \\
(0.0043)\end{array}$ & $\begin{array}{l}-0.0071 * \\
(0.0043)\end{array}$ \\
\hline $\begin{array}{c}\text { Public social protection } \\
\text { expenditures as \% of GDP (in } \\
\text { logs, lagged) }\end{array}$ & $\begin{array}{r}0.0036^{* *} \\
(0.0017)\end{array}$ & $\begin{array}{c}0.0052 \\
(0.0018)\end{array}$ & $\begin{array}{c}0.0042 * * \\
(0.0016)\end{array}$ & $\begin{array}{l}0.0047 * * * \\
(0.0015)\end{array}$ \\
\hline Population growth (lagged) & $\begin{array}{c}-0.0306^{* *} \\
(0.0120)\end{array}$ & & & $\begin{array}{c}-0.0556 * * * \\
(0.0119)\end{array}$ \\
\hline Inflation (in logs, lagged) & & $\begin{array}{l}-0.0037 * \\
(0.0021)\end{array}$ & & \\
\hline Investment (lagged) & $\begin{array}{c}0.3619 * * * \\
(0.0868)\end{array}$ & & & \\
\hline Terms of trade (lagged) & & $\begin{array}{c}-0.0011 * * * \\
(0.0002)\end{array}$ & & \\
\hline Voice and accountability & & & $\begin{array}{c}-0.2425^{* * *} \\
(0.0584)\end{array}$ & $\begin{array}{c}0.1739 * * * \\
(0.0408)\end{array}$ \\
\hline $\begin{array}{l}\text { Political stability and no violence } \\
\text { (lagged) }\end{array}$ & & & $\begin{array}{c}-0.1148 * * * \\
(0.0164)\end{array}$ & \\
\hline $\begin{array}{c}\text { Government effectiveness } \\
\text { (lagged) }\end{array}$ & & & $\begin{array}{c}0.2729 * * * \\
(0.0541)\end{array}$ & $\begin{array}{r}0.0868 * * \\
(0.0373)\end{array}$ \\
\hline Rule of law (lagged) & & & $\begin{array}{l}-0.0623 \\
(0.0396)\end{array}$ & \\
\hline Regulatory quality (lagged) & & & $\begin{array}{c}-0.5742 * * * \\
(0.0615)\end{array}$ & \\
\hline Control of corruption (lagged) & & & $\begin{array}{c}0.1693^{* * * *} \\
(0.0394)\end{array}$ & \\
\hline Observations & 919 & 934 & 934 & 919 \\
\hline R2 & 0.99 & 0.99 & 0.99 & 0.99 \\
\hline P-value & 0 & 0 & 0 & 0 \\
\hline Period & 20 & 21 & 21 & 20 \\
\hline Cross-sections (countries) & 60 & & 60 & 60 \\
\hline $\begin{array}{l}\text { Cross-country fixed effects } \\
\text { (including dummy) }\end{array}$ & yes & yes & yes & yes \\
\hline $\begin{array}{c}\text { Cross-section weight (dummy } \\
\text { variables) }\end{array}$ & yes & yes & yes & yes \\
\hline Period fixed (dummy variables) & no & no & no & no \\
\hline $\begin{array}{l}\text { Robust standard errors in parentheses } \\
* * * p<0.01, * * p<0.05,{ }^{*} p<0.1\end{array}$ & & & & \\
\hline
\end{tabular}


Table 5. Robustness Checks for GNI and Public Social Spending (continued)

\begin{tabular}{|c|c|c|c|c|}
\hline \multirow[b]{2}{*}{ Explanatory variable } & \multicolumn{4}{|c|}{$\begin{array}{l}\text { Dependent variable GNI per capita } \\
\text { (in logs) }\end{array}$} \\
\hline & $\begin{array}{l}\text { Fixed effects } \\
\text { OLS }\end{array}$ & & $\begin{array}{l}\text { Fixed effects } \\
\text { OLS }\end{array}$ & $\begin{array}{l}\text { Fixed effects } \\
\text { OLS }\end{array}$ \\
\hline Specifications & (8) & (9) & (10) & (11) \\
\hline Constant & $\begin{array}{l}0.6645 * * * \\
(0.0718)\end{array}$ & $\begin{array}{c}0.9294 * * * \\
(0.0987)\end{array}$ & $\begin{array}{l}0.4548 * * * \\
(0.0979)\end{array}$ & $\begin{array}{l}0.6610^{* * *} \\
(0.1089)\end{array}$ \\
\hline $\begin{array}{l}\text { Public education expenditures as } \\
\% \text { of GDP (in logs, lagged) }\end{array}$ & $\begin{array}{r}0.0175 * * \\
(0.0076)\end{array}$ & $\begin{array}{c}0.0189 * * \\
(0.0079)\end{array}$ & $\begin{array}{l}0.0212 * * * \\
(0.0979)\end{array}$ & $\begin{array}{l}0.0164 * * \\
(0.0079)\end{array}$ \\
\hline $\begin{array}{l}\text { GNI per capita in } 2011 \text { PPPs } \$ \\
\text { prices (in logs, lagged as an } \\
\text { explanatory variable) }\end{array}$ & $\begin{array}{l}0.9264 * * * \\
(0.007853)\end{array}$ & $\begin{array}{c}0.9103 * * * \\
(0.0120)\end{array}$ & $\begin{array}{l}0.9441 * * * \\
(0.0092)\end{array}$ & $\begin{array}{l}0.9282 * * * \\
(0.0125)\end{array}$ \\
\hline $\begin{array}{l}\text { Public health expenditures as \% } \\
\text { of GDP (in logs, lagged) }\end{array}$ & $\begin{array}{l}-0.0097 * * \\
(0.0042)\end{array}$ & $\begin{array}{c}-0.0129 * * \\
(0.0055)\end{array}$ & $\begin{array}{l}-0.0081^{*} \\
(0.0043)\end{array}$ & $\begin{array}{l}-0.0096^{*} \\
(0.0056)\end{array}$ \\
\hline $\begin{array}{c}\text { Public social protection } \\
\text { expenditures as } \% \text { of GDP (in } \\
\text { logs, lagged) }\end{array}$ & $\begin{array}{l}0.0036^{* *} \\
(0.0017)\end{array}$ & $\begin{array}{c}0.0030 \\
(0.0018)\end{array}$ & $\begin{array}{l}0.0035^{* *} \\
(0.0016)\end{array}$ & $\begin{array}{l}0.0037 * * \\
(0.0018)\end{array}$ \\
\hline Population growth (lagged) & $\begin{array}{c}-0.0306^{* *} \\
(0.0120)\end{array}$ & & & \\
\hline Inflation (in logs, lagged) & & $\begin{array}{c}0.0158 * * \\
(0.0021)\end{array}$ & & $\begin{array}{c}0.0157 * * \\
(0.0067)\end{array}$ \\
\hline Investment rate (lagged) & $\begin{array}{c}0.3619^{* * *} \\
(0.0868)\end{array}$ & & & $\begin{array}{l}-0.0020^{* * * *} \\
(0.0064)\end{array}$ \\
\hline Terms of trade (lagged) & & $\begin{array}{c}-0.0015 * * * \\
(0.0002)\end{array}$ & & $\begin{array}{l}-0.0075^{* * *} \\
(0.0026)\end{array}$ \\
\hline Voice and accountability & & & $\begin{array}{l}0.1089^{* * *} \\
(0.0406)\end{array}$ & \\
\hline Political stability and no violence & & & $\begin{array}{c}0.0331 * * * \\
(0.0126)\end{array}$ & \\
\hline Government effectiveness & & & $\begin{array}{l}0.0632^{*} \\
(0.0343)\end{array}$ & \\
\hline Rule of law & & $\begin{array}{c}0.0793 * * * \\
(0.0301)\end{array}$ & & \\
\hline Control of corruption & & & & $\begin{array}{c}0.2195^{* * *} \\
(0.1089)\end{array}$ \\
\hline Observations & 919 & 934 & 934 & 919 \\
\hline R2 & 0.99 & 0.99 & 0.99 & 0.99 \\
\hline P-value & 0 & 0 & 0 & 0 \\
\hline Period & 20 & 21 & 21 & 20 \\
\hline Cross-sections (countries) & 60 & & 60 & 60 \\
\hline $\begin{array}{l}\text { Cross-country fixed effects } \\
\text { (including dummy) }\end{array}$ & yes & yes & yes & yes \\
\hline $\begin{array}{l}\text { Cross-section weight (dummy } \\
\text { variables) }\end{array}$ & yes & Yes & yes & yes \\
\hline Period fixed (dummy variables) & no & No & no & no \\
\hline
\end{tabular}




\section{B. Expected Years of Schooling and Public Educational Spending}

For checking robustness of our results for the impact of social spending on expected years of schooling we include in the equation (1) as control variables: total population in logs, population growth, inflation in logs, literacy rate in logs, Gini index in logs, voice and accountability and rule of law. We also apply GMM estimator using equation (2). The results are reported in Table 6.

The inclusion of control variables in the regression leads to similar response coefficients as in the specification with a lagged dependent variable. The basic econometric results show that a 1 percent increase in public educational spending results in 0.014 percent short run positive difference in expected years of schooling in specification with a lagged dependent variable in specification (1). The results with the Gini index in specification (2), and population growth, literacy rate in specification (5) lead to the same results. Controlling for variety of other factors in specifications (4) and (5), such as rule of law and voice and accountability, regressions between expected years of schooling and public educational spending show that the relationship is robust, and the coefficients remain similar.

In the specification (3) we use the GMM estimator with fixed effects and instrumental variables second lag of the dependent and explanatory variable and total population (in logs), which confirms the magnitude of the relationship between expected years of schooling and public educational spending to 0.016 percent.

Table 6. Robustness Checks for Expected Years of Schooling

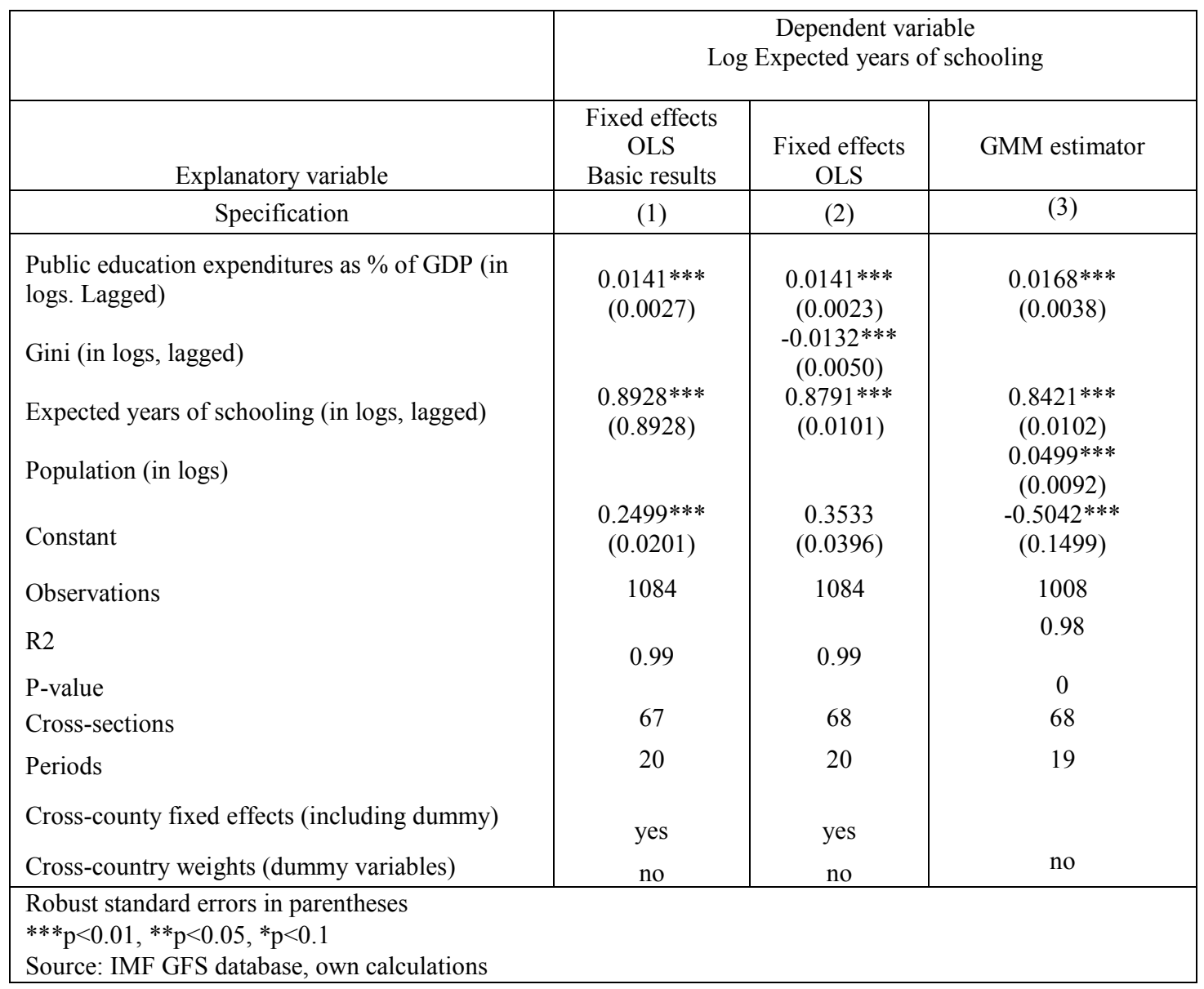


Table 6. Robustness Checks for Expected Years of Schooling (continued)

\begin{tabular}{|c|c|c|}
\hline \multirow[b]{2}{*}{ Explanatory variable } & \multicolumn{2}{|c|}{$\begin{array}{c}\text { Dependent variable } \\
\text { Log Expected years of schooling }\end{array}$} \\
\hline & $\begin{array}{l}\text { Fixed effects } \\
\quad \text { OLS }\end{array}$ & $\begin{array}{l}\text { Fixed effects } \\
\text { OLS }\end{array}$ \\
\hline Specifications & (4) & $(5)$ \\
\hline $\begin{array}{l}\text { Public education expenditures as } \\
\% \text { of GDP (in logs, lagged) }\end{array}$ & $\begin{array}{c}0.0139 * * * \\
(0.0026)\end{array}$ & $\begin{array}{c}0.0148^{* * *} \\
(0.0027)\end{array}$ \\
\hline Total population (in logs, lagged) & $\begin{array}{c}0.0438 * * * \\
(0.0087)\end{array}$ & \\
\hline Population growth (lagged) & & $\begin{array}{l}0.0126 * * * \\
(0.0045)\end{array}$ \\
\hline Literacy rate (in logs, lagged) & & $\begin{array}{l}-0.0609 * * * \\
(0.0177)\end{array}$ \\
\hline Voice and accountability & & $\begin{array}{c}-0.0275^{* *} \\
(0.0159)\end{array}$ \\
\hline Rule of law & $\begin{array}{c}-0.0365 * * * \\
(0.0140)\end{array}$ & \\
\hline $\begin{array}{l}\text { Expected years of schooling (in } \\
\text { logs, lagged) }\end{array}$ & $\begin{array}{c}0.8684 * * * \\
(0.0088)\end{array}$ & $\begin{array}{c}0.8686^{* * *} \\
(0.0082)\end{array}$ \\
\hline Constant & $\begin{array}{c}-0.4428 * * * \\
(0.1416)\end{array}$ & $\begin{array}{c}0.6056^{* * *} \\
(0.0884)\end{array}$ \\
\hline Observations & 495 & 1067 \\
\hline $\mathrm{R} 2$ & 0.99 & 0.99 \\
\hline P-value & 0 & 0 \\
\hline Period & 8 & 19 \\
\hline Cross-sections (countries) & 68 & 68 \\
\hline $\begin{array}{l}\text { Cross-country fixed effects } \\
\text { (including dummy) }\end{array}$ & yes & yes \\
\hline $\begin{array}{l}\text { Cross-section weight (dummy } \\
\text { variables) }\end{array}$ & yes & yes \\
\hline Period fixed (dummy variables) & no & no \\
\hline $\begin{array}{l}\text { Robust standard errors in parentheses } \\
* * * p<0.01, * * p<0.05,{ }^{*}<<0.1 \\
\text { Source: IMF GFS database, own calcu }\end{array}$ & & \\
\hline
\end{tabular}

\section{Life Expectancy and Public Health Spending}

To check robustness of our results for the estimations of social spending and life expectancy we include control variables in equation (1), including total population in logs, population growth, literacy rate in logs, Gini index in logs, GNI per capita in logs. We also apply the GMM estimator. The results are reported in Table 7.

We compare the results for life expectancy as the dependent variable as a function of public health expenditures, using only the lagged dependent variable in the specification (1), and introducing GNI per capita and the Gini index as controls in specifications (2) and (3). The specifications display similar results. A 1 percent increase in public health spending results in 0.0009 percent positive difference in life expectancy. Including control variables of total 
population and literacy rate in specification (5) show that the relationship between life expectancy and public health spending is still robust.

Using the GMM estimator and additional instrumental variables total population (in logs) and literacy rate (in logs) in the specification (4) the results show smaller as magnitude relationship of 0.0003 percent in short run.

Table 7. Robustness Checks for Life Expectancy

\begin{tabular}{|c|c|c|c|}
\hline \multirow[b]{3}{*}{ Explanatory variable } & \multicolumn{3}{|c|}{ Dependent variable } \\
\hline & \multicolumn{3}{|c|}{ Log Life expectancy } \\
\hline & $\begin{array}{c}\text { Fixed effects } \\
\text { OLS } \\
\text { Basic results }\end{array}$ & $\begin{array}{c}\text { Fixed effects } \\
\text { OLS }\end{array}$ & $\begin{array}{c}\text { Fixed effects } \\
\text { OLS }\end{array}$ \\
\hline Specification & (1) & (2) & (3) \\
\hline $\begin{array}{l}\text { Public health expenditures as \% of } \\
\text { GDP (in logs, lagged) }\end{array}$ & $\begin{array}{l}0.0005^{* *} \\
(0.0001)\end{array}$ & $\begin{array}{l}0.0009 * * * \\
(0.0003)\end{array}$ & $\begin{array}{l}0.0007 * * \\
(0.0002)\end{array}$ \\
\hline $\begin{array}{l}\text { GNI per capita in } 2011 \text { PPPs } \$ \text { prices } \\
\text { (in logs, lagged) }\end{array}$ & & $\begin{array}{l}0.0025 * * * \\
(0.0025)\end{array}$ & \\
\hline Gini index (in logs, lagged) & & & $\begin{array}{l}-0.0081 * * \\
(0.0017)\end{array}$ \\
\hline Life expectancy (in logs, lagged) & $\begin{array}{c}0.9752 * * * \\
(0.0022)\end{array}$ & $\begin{array}{l}0.9704 * * * \\
(0.0070)\end{array}$ & $\begin{array}{l}0.9567 * * \\
(0.0075)\end{array}$ \\
\hline Population (in logs, lagged) & & & \\
\hline Literacy rate (in logs, lagged) & & & \\
\hline Constant & $\begin{array}{c}0.1092 \\
(0.0096)\end{array}$ & $\begin{array}{c}0.1052 \\
(0.0188)\end{array}$ & $\begin{array}{l}0.2171 \\
(0.0386)\end{array}$ \\
\hline Observation & 1081 & 953 & 1081 \\
\hline $\mathrm{R} 2$ & 0.99 & 0.99 & 0.99 \\
\hline P-value & 0 & 0 & 0 \\
\hline Cross-sections & 67 & 66 & 67 \\
\hline Periods & 20 & 20 & 20 \\
\hline $\begin{array}{l}\text { Cross-country fixed effects (including } \\
\text { dummy) }\end{array}$ & yes & yes & yes \\
\hline $\begin{array}{l}\text { Cross-country weights (dummy } \\
\text { variables) }\end{array}$ & yes & no & no \\
\hline $\begin{array}{l}\text { Robust standard errors in parentheses } \\
* * * p<0.01, * * p<0.05, * p<0.1\end{array}$ & & & \\
\hline
\end{tabular}


Table 7. Robustness Checks for Life Expectancy (continued)

\begin{tabular}{|c|c|c|}
\hline \multirow[b]{3}{*}{ Explanatory variable } & \multicolumn{2}{|c|}{ Dependent variable } \\
\hline & \multicolumn{2}{|c|}{ Log Life expectancy } \\
\hline & GMM & $\begin{array}{l}\text { Fixed effects } \\
\text { OLS }\end{array}$ \\
\hline Specifications & (4) & (5) \\
\hline Constant & $\begin{array}{l}-0.1841 * * * \\
(0.0707)\end{array}$ & $\begin{array}{l}-0.1066^{* * *} \\
(0.0764)\end{array}$ \\
\hline $\begin{array}{l}\text { Public health expenditures as \% } \\
\text { of GDP (in logs, lagged) }\end{array}$ & $\begin{array}{c}0.0003^{* * *} \\
(0.0001)\end{array}$ & $\begin{array}{c}0.0002 * * \\
(0.0001)\end{array}$ \\
\hline $\begin{array}{l}\text { GNI per capita in } 2011 \text { PPPs } \$ \\
\text { prices (in logs, lagged) }\end{array}$ & $\begin{array}{c}0.9293 * * * \\
(0.0036)\end{array}$ & \\
\hline Total population (in logs, lagged) & $\begin{array}{c}0.0224 * * * \\
(0.0023)\end{array}$ & $\begin{array}{l}0.0065^{* * *} \\
(0.0027)\end{array}$ \\
\hline Literacy rate (in logs, lagged) & $\begin{array}{c}0.01880^{* *} \\
(0.0078)\end{array}$ & $\begin{array}{r}0.0139 * * * \\
(0.0077)\end{array}$ \\
\hline Life expectancy (in logs, lagged) & $\begin{array}{c}0.9726 * * * \\
(0.0023)\end{array}$ & $\begin{array}{l}0.9834 * * * \\
(0.0011)\end{array}$ \\
\hline Observations & 1004 & 1081 \\
\hline $\mathrm{R} 2$ & 0.99 & 0.99 \\
\hline P-value & 0 & 0 \\
\hline Period & 67 & 20 \\
\hline Cross-sections (countries) & 19 & 67 \\
\hline $\begin{array}{l}\text { Cross-country fixed effects } \\
\text { (including dummy) }\end{array}$ & & yes \\
\hline $\begin{array}{l}\text { Cross-section weight (dummy } \\
\text { variables) }\end{array}$ & & yes \\
\hline Period fixed (dummy variables) & & no \\
\hline
\end{tabular}

\section{CONCLUSION}

The 2030 Agenda for Sustainable Development recognizes that ending poverty and other deprivations must go together with strategies that improve health and education and spur economic growth. In general, our study displays positive long run effects of public educational spending and social spending on GNI per capita, of public educational spending on expected years of schooling, and public health spending on life expectancy. Controlling for factors that simultaneously affect both variables by including country fixed effects, a lagged dependent variable, and alternative control variables, the estimates establish a significant statistical association between GNI per capita and public educational spending.

The empirical findings of this study provide the following conclusions: First, the estimated regression coefficients of public educational spending display positive small effects on GNI per capita in the short run and larger effects in long run. The estimates for health show no evidence 
of effects on GNI per capita when appropriate controls are included, while the effects of social protection are statistically significant, but much small as magnitude than educational spending.

Second, the OLS estimator with fixed cross-country effects in the equation for expected years of schooling indicate a straightforward positive relation with public educational spending, and with reduced income inequality in long run. The estimated effects suggest that the direction of causation from public educational spending to expected years of schooling is not immediate; rather, investment in education is expected to affect years of schooling after some period. The estimates are consistent with the findings of causality running from public educational spending to economic growth in the research of Barro (2001), Barro and Lee (2005), Jiranyakul and Brahmasrene (2007), Chandra and Islamia (2010).

Third, the study finds that the relationship between public health spending and life expectancy is statistically significant and larger in long run compared to the immediate effect. The findings are consistent with the estimates of Link and Phelan (1995), Fritzell and Lundberg (2007), Jaba et al. (2014) and Leitner and Stehler (2016) for the EU countries. 


\section{References}

Acemoglu, D., Johnson S., Robinson J.A., Yared P., 2008. "Income and Democracy." American Economic Review 98 (3): 808-42.

Andersen T.R., Hsiao C., 1982, Formulation and Estimation of Dynamic Models Using Panel Data, Journal of Econometrics, 18(1):47-82

Arellano M., Bond S.R., 1991, Some Tests of Specifications for Panel: Monte Carlo Evidence and an Application to Employment Equations, Review if Economic Studies, 58(2):277-97

Aschauer D., 1989, Is public expenditure productive, Journal Monetary Economics, Volume 23, Issues 2, p. 177-200

Baltagi, B.H. (2005) Econometric Analysis of Panel Data. 3rd Edition, John Wiley \& Sons Inc., New York

Barro R., 2001, Human Capital and Growth, The American Economic Review, Vol. 91, No 2, pp. 12-17

Barro R., 2003, Determinants of Economic Growth in a Panel of Countries, The Annals of Economics and Finance 4, 231 -274

Barro, R., and Lee J.W., 2015, Education Matters: Global Schooling Gains from the 19th to the 21st Century, Oxford University Press New York

Basu P., Bhattarai K, 2009, Does Government Spending on Education Promote Growth and Schooling Returns?

Bauer, P.W., Schweitzer M.E., and Shane S., 2006, State Growth Empirics: The Long-Run Determinants of State Income Growth. Federal Reserve Bank of Cleveland Working Paper 0606.

Becker, G., 1964, Human capital — a theoretical and empirical analysis, with special reference to education, National Bureau of Economic Research, New York.

Benabou 2000, Unequal Societies: Income Distribution and the Social Contract, The American Economic Review, vol. 90, No1 (March 2000), 96-129

Benhabib, J., and Spiegel M.M., 1994, The role of human capital in economic development Evidence from aggregate cross-country data." Journal of Monetary Economics 34, p. 143-173

Beramendi P., Wibbels E., 2015, Globalization, Public Finance, and Poverty, 2015, International Studies Review

Blanchard, Olivier and Robert Perotti. "An Empirical Characterization Of The Dynamic Effects Of Changes In Government Spending And Taxes On Output," Quarterly Journal of Economics, 2002, v107(4,Nov), 1329-1368

Bose, Haque and Osborn, 2003, Public Expenditure and Economic Growth: A Disaggregated Analysis for Developing Countries 
Bontout O., Lokajickova, Social protection budgets in the crisis in the EU, European Commission, WP 1/2013

Bruegel database, http://bruegel.org/publications/datasets/global-and-regional-gini-coefficients/

Chandra A., Islamia J. M., 2010, Does Government Expenditure on Education Promote Economic Growth? An Econometric Analysis, Munich Personal RePEc Archive

Davis (2002), Estimating multi-way error components models with unbalanced data structures, Journal of Econometrics, 2002, vol. 106, issue 1, 67-95

De la Croix D., Delavallade C., Growth, public investment and corruption with failing institutions, Working paper 2007-61, Society for the Study of Economic Inequality (2006) Delong J.B., Goldin C., Katz L.F., 2003, Sustaining U.S. economic growth. In: Aaron H (ed) Agenda for the nation. The Brookings Institution, Washington, p 17-60.

DeMooij and Hofstede, 2002, Cross-Cultural Consumer Behavior: A Review of Research Findings, Journal of International Consumer Marketing, 23:181-192, 2011

Fournier J.-M., Johansson, 2016, The effect of the size and the mix of public spending on growth and inequality, OECD, WP 1344

Fritzell and Lundberg 2007, Health inequalities and welfare resources: Continuity and change in Sweden, Bristol: Policy Press

Gáspár, A., 2012, Convergence analysis: a new approach. Published in: Crisis Aftermath: Economic policy changes in the EU and its Member States, Conference Proceedings, Szeged, University of Szeged, Vol. ISBN 9, (2012): pp. 382-390.

Glaeser, E. and Saiz A., 2004, The Rise of the Skilled City, Brookings-Wharton Papers on Urban Affairs.

Goerl C.-A., Seiferling M., 2014, Income Inequality, Fiscal Decentralization and Transfer Dependency, International Monetary Fund, WP/14/64

Herrera S., 2007, Public Expenditure and growth, World Bank, WPS4372

Human Development Indices and Indicators: 2018 Statistical Update, 2018, United Nations Development Program

IMF Database: https://www.imf.org/en/Data

International Labor Organization, 2017, World Social Protection Report 2017-19: Universal social protection to achieve the Sustainable Development Goals, p. 119

Jaba E., Balan C. B., Robu I.B., 2014, The relationship between life expectancy at birth and health expenditures estimated by a cross-country and time-series analysis, Procedia Economics and Finance 15 (2014) $108-114$

Jiranyakul and Brahmasrene (2007), Government spending, money supply and economic growth: evidence from Tailand 
Jones C. and Klenow (2010), Beyond GDP? Welfare across Countries and Time, American Economic Review 2016, 106(9): 2426-2457

Kolm S.-Ch., 1977, Multidimensional Egalitarianisms, The Quarterly Journal of Economics, vol. 91, issue 1, 1-13

Levine r. and Renelt D., 1992, "A Sensitivity Analysis of Cross-Country Growth Regressions," American Economic Review, American Economic Association, vol. 82(4), pages 942-963,

Leitner S., Stehrer R., 2016, Development of Public Spending Structures in the EU Member States: Social Investment and its Impact on Social Outcomes, WP 128, Vienna Institute for International Economic Studies

Link B., Phelan J., 1995, Social Conditions as Fundamental Causes of Disease, Journal of Health and Social Behavior, (Extra Issue), 80-94

Melo and Tiongson, 2003, Income Inequality and Redistributive Government Spending, International Monetary Fund, WP/03/14

Miguel Niño-Zarazúa, 2017, Does Social Spending Improve Welfare in Low-income and Middle-income Countries?

Mittnik S. and Neumann T., 2003, Time-Series Evidence on the Nonlinearity Hypothesis for Public Spending, Economic Inquiry, 2003, vol. 41, issue 4, 565-573

Nelson K, Fritzell J., Welfare states and population health: The role of minimum income benefits for mortality

Novak J., Kochkova O., 2011, Income Culture, and Household Consumption Expenditure Patterns in the Europena Union: Convergence or Divergence? Journal of International Consumer Marketing, 23:3-4, 260-275

OECD Better Life Initiative: Measuring Well-Being and Progress: http://www.oecd.org/statistics/better-life-initiative.htm

Pagano, P. 2004. An empirical investigation of the relationship between inequality and growth. Banca d'Italia, Temi di discussione del Serivzio Studi. No. 536.

Rama M., Beteille T., Li Y., Pradeep K.M., and Newman L., 2015, Addressing Inequality in South Asia, World Bank, page 116

Reza Baqir, 2002, Social Sector Spending in a Panel of Countries, International Monetary Fund, $\mathrm{WP} / 02 / 35$

Seiferling M., Tareq S., 2015, Fiscal Transparency and the Performance of Government Financial Assets, IMF, WP/15/9

Seiferling M., 2013, Recent Improvements to the Government Finance Statistics Yearbook Database in Response to Analytical Needs 
Spilimbergo A., Symansky S., and Schindler M., 2009, Fiscal Multipliers, IMF Staff Position Note 09/11, Washington: International Monetary Fund

United Nations, 2016, Human development report, Human Development for Everyone

World Bank, 2018, World Development Report, Learning to Realize Education's Promise, Washington, DC

World Bank, 2014, Student Learning in South Asia: Challenges, Opportunities, and Policy Priorities, Washington, DC

World Bank, 2012, Golden Growth - restoring the luster of the European economic model, Washington, DC

United Nations’' Database: http://data.un.org/Explorer.aspx?d=WDI;

United Nations' HDI database: http://hdr.undp.org/en/data

United Nations' 2030 Agenda for Sustainable Development:

https://www.un.org/sustainabledevelopment/development-agenda/

Yamarik S., 2010, Human capital and state-level economic growth: what is the contribution of schooling?, The Annals of Regional Science. August 2011, Volume 47, Issue 1, p. 195-211 
APPENDiX I. COUNTRIES RePorted For THE IMF GFS YEARbOOK USED The SAMPLE

\begin{tabular}{|c|c|c|}
\hline Countries & & Level of government represented in the samples \\
\hline Albania & ALB & General government \\
\hline Angola & $\mathrm{AGO}$ & Budgetary central government \\
\hline Australia & AUS & General government \\
\hline Austria & AUT & General government \\
\hline $\begin{array}{l}\text { Azerbaijan, } \\
\text { Republic of }\end{array}$ & AZE & General government \\
\hline Bangladesh & BGD & Budgetary central government \\
\hline Belarus & BLR & General government \\
\hline Belgium & BEL & General government \\
\hline Bhutan & BTN & General government \\
\hline Bulgaria & BGR & General government \\
\hline Chile & $\mathrm{CHL}$ & Central government (incl. social security funds) \\
\hline $\begin{array}{l}\text { China, P.R.: } \\
\text { Mainland }\end{array}$ & $\mathrm{CHN}$ & General government \\
\hline Costa Rica & CRI & Budgetary central government \\
\hline Croatia & HRV & Budgetary central government \\
\hline $\begin{array}{l}\text { Czech } \\
\text { Republic }\end{array}$ & CZE & General government \\
\hline Denmark & DNK & General government \\
\hline Egypt & EGY & General government \\
\hline El Salvador & SLV & Central government (incl. social security funds) \\
\hline Estonia & EST & General government \\
\hline Finland & FIN & General government \\
\hline France & FRA & General government \\
\hline Georgia & GEO & General government \\
\hline Germany & DEU & General government \\
\hline Greece & GRC & General government \\
\hline Guatemala & GTM & Budgetary central government \\
\hline Hungary & HUN & General government \\
\hline Iceland & ISL & General government \\
\hline India & IND & Budgetary central government \\
\hline Ireland & IRL & General government \\
\hline Israel & ISR & General government \\
\hline Italy & ITA & General government \\
\hline Jamaica & JAM & Budgetary central government \\
\hline Japan & JPN & General government \\
\hline Jordan & JOR & Budgetary central government \\
\hline Kazakhstan & KAZ & General government \\
\hline Kenya & KEN & Budgetary central government \\
\hline Latvia & LVA & General government \\
\hline Lithuania & LTU & General government \\
\hline Madagascar & MDG & Central government (incl. social security funds) \\
\hline Malaysia & MYS & Budgetary central government \\
\hline
\end{tabular}




\begin{tabular}{|c|c|c|}
\hline Maldives & MDV & General Government \\
\hline Mauritius & MUS & General government \\
\hline Moldova & MDA & General government \\
\hline Namibia & NAM & Budgetary central government \\
\hline Nepal & NPL & Budgetary central government \\
\hline Netherlands & NLD & General government \\
\hline New Zealand & NZL & General government \\
\hline Norway & NOR & General government \\
\hline Oman & $\mathrm{OMN}$ & Budgetary central government \\
\hline Pakistan & PAK & Budgetary central government \\
\hline Philippines & PHL & Budgetary central government \\
\hline Poland & POL & General government \\
\hline Portugal & PRT & General government \\
\hline Romania & ROM & General government \\
\hline $\begin{array}{l}\text { Russian } \\
\text { Federation }\end{array}$ & RUS & al government \\
\hline Seychelles & SYC & General government \\
\hline $\begin{array}{l}\text { Slovak } \\
\text { Republic }\end{array}$ & SVK & General government \\
\hline Slovenia & SVN & General government \\
\hline South Africa & ZAF & General government \\
\hline Spain & ESP & General government \\
\hline Sri Lanka & LKA & Budgetary central government \\
\hline Sweden & SWE & General government \\
\hline Switzerland & $\mathrm{CHE}$ & General government \\
\hline Thailand & THA & Budgetary central government \\
\hline Uganda & UGA & Budgetary central government \\
\hline Ukraine & UKR & General government \\
\hline $\begin{array}{l}\text { United } \\
\text { Kingdom }\end{array}$ & GBR & $\mathrm{Ge}$ \\
\hline United States & USA & General government \\
\hline
\end{tabular}




\section{APPENDIX II. DATA METHODOLOGY AND TESTS}

Human Development Index: The HDI is the geometric mean of indices assessing these three dimensions transforming their minimum and maximum values into a scale of 0 to 1 - indices of education, health and income. It differentiates countries into several categories of human development - countries with very high level (HDI above 0.8), high level (HDI above 0.7), medium level (HDI 0.56-0.7), and low level (HDI below 0.56) ${ }^{40}$.

Table 11. Dimensions of HDI

\begin{tabular}{|l|l|c|c|}
\hline Dimension & Indicator & Minimum & Maximum \\
\hline Health & Life expectancy (years) & 20 & 85 \\
\hline Education & $\frac{\text { Expected years of schooling }}{\text { Mean years of schooling }}$ & 0 & 18 \\
\hline $\begin{array}{l}\text { Standard } \\
\text { of Living }\end{array}$ & $\begin{array}{l}\text { Gross National Income per } \\
\text { capita (in PPP in \$) }\end{array}$ & 100 & 75000 \\
\hline
\end{tabular}

Source: United Nations, Human Development Report 2017, Technical Notes

Public Social Expenditures: We apply the broad concept for public social spending, which includes: (i) health; (ii) education, and (iii) social protection (table 15). COFOG data on public social spending are based on the COFOG methodology for functions of government expenditures described in the GFSM 2014. COFOG is a detailed classification of socioeconomic objectives that government aims to achieve through various kinds of expenditure. COFOG permits trends in government expenditure and is also used for making international comparisons of the extent to which governments are involved in particular economic and social functions. All government spending entails redistribution, but certain outlays have more explicit redistributive roles in achieving social outcomes. At the most aggregated level public expenditures are classified by ten COFOG categories, which indicate public services for individual consumption $^{41}$ and services for collective consumption ${ }^{42}$. Some sub-items of individual services are considered collective ${ }^{43}$. Social public spending, subject of our analysis, includes expenditures on health, education and social protection, which are mostly part of individual consumption of households.

Table 8. GFS Functions of Government for Social Spending (GFSM 2014)

\begin{tabular}{|l|l|l|}
\hline Health & Education & Social protection \\
\hline Medical products, & Pre-primary and primary & Sickness and disability \\
appliances, and equipment & education & Old age \\
Outpatient services & Secondary education & Survivors \\
Hospital services & Postsecondary non-tertiary & Family and children \\
Public health services & education & Unemployment \\
R\&D Health & Tertiary education & Housing \\
\hline
\end{tabular}

40 See HDI levels at: http://hdr.undp.org/en/composite/HDI

${ }^{41}$ Health; Recreation, culture and religion; Education; and Social protection

${ }^{42}$ General public services; Defense; Public order and safety; Economic affairs; Environment protection; and Housing and community amenities. These services are provided simultaneously to all members of the community.

${ }^{43}$ R\&D health, health not anywhere classified; broadcasting and publishing services; religion and other community services etc. 


\begin{tabular}{|l|l|l|l|}
\hline Health n.e.c. & Education not definable by & & Social exclusion n.e.c. \\
& level & R\&D Social protection \\
Subsidiary services to & & Social protection n.e.c. \\
& education & & \\
& R\&D Education & & \\
Education n.e.c. & & \\
\hline
\end{tabular}

GINI index as control variable ${ }^{44}$ : In the WB's methodology no adjustment has been made for spatial differences in cost of living within countries, because the data needed for such calculations are generally unavailable. Survey year is the year in which the underlying household survey data were collected or, when the data collection period bridged two calendar years, the year in which most of the data were collected.

The Gini index measures the area between the Lorenz curve and a hypothetical line of absolute equality, expressed as a percentage of the maximum area under the line. A Lorenz curve plots the cumulative percentages of total income received against the cumulative number of recipients, starting with the poorest individual. Thus, a Gini index of 0 represents perfect equality, while an index of 100 implies perfect inequality. The Gini index provides a convenient summary measure of the degree of inequality, but it has its limitations. It is possible for two different Lorenz curves to give rise to the same Gini coefficient. Furthermore, it is possible for the Gini coefficient of a developing country to rise (due to increasing inequality of income) while the number of people in absolute poverty decreases. This is because the Gini coefficient measures relative, not absolute, wealth.

Statistical concept and methodology: Data on the distribution of income or consumption come from nationally representative household surveys. Where the original data from the household survey were available, they have been used to calculate the income or consumption shares by quintile. Otherwise, shares have been estimated from the best available grouped data. The distribution data have been adjusted for household size, providing a more consistent measure of per capita income or consumption. No adjustment has been made for spatial differences in cost of living within countries, because the data needed for such calculations are generally unavailable. For further details on the estimation method for low- and middle-income economies, see Ravallion and Chen (1996). Survey year is the year in which the underlying household survey data were collected or, when the data collection period bridged two calendar years, the year in which most of the data were collected.

We performed the univariate time series data analysis to assess the behavior of economic variables. To address the common concern over the creation of spurious regressions (Granger and Newbold 1974), each time series used in the model was tested for stationarity using panel unit root tests. The practical outcomes of testing for stationarity was to determine whether each variable is most appropriately entered in levels or in first differences. The null hypothesis assumes the series have unit root or is not stationary. An individual intercept is included in each panel unit root test where indicated in the results. The weight of results suggests that the log transformation of the time series variables produces series that are stationary. The test for natural logarithms of public spending time series rejects the null hypothesis that the time series have unit root. The probability of having unit root is zero in one of the methods of Levin, Lin and Chu. The other methods of Im, Pesaran and Shin, ADF and PP confirm it at level of

\footnotetext{
${ }^{44}$ https://data.worldbank.org/indicator/SI.POV.GINI
} 
confidence between 90 and 99 percent. The tests for data in natural logarithms of other dependent and control variables are stationary in levels.

Granger causality test with six lags indicates bi-directional causality between GNI per capita and public spending on education and health spending at the 10 percent significance level, with two lags one-directional causality from GNI per capita to public spending on social protection, and one-directional causality of public spending on life expectancy and expected years of schooling (Table 2). However, these bivariate tests do not control for other factors, and therefore give limited information about relations between variables. The regressions presented in the next section of the paper include other controls and therefore give a more complete picture.

Table 9. Granger Causality Test

Causality between public social spending (in logs, share of GDP) and GNI per capita (in logs)

Pairwise Granger Causality Tests

Lags: 6

\begin{tabular}{|lll|}
\hline \hline Null Hypothesis: & Obs & F-Statistic Prob. \\
\hline
\end{tabular}

GNI per capita (in logs) does not Granger Cause Public educational expenditures (in logs, share of GDP)

Public educational expenditures (in logs, share of GDP) does not Granger Cause GNI per $\begin{array}{lll}618 & 1.87502 & 0.0829\end{array}$ capita (in logs)

Lags: 6

\begin{tabular}{|c|c|c|c|}
\hline Null Hypothesis: & Obs & F-Statistic & Prob. \\
\hline $\begin{array}{l}\text { GNI per capita (in logs) does not Granger Cause Public health expenditures (in } \\
\text { logs, share of GDP) }\end{array}$ & 607 & 3.78057 & 0.0011 \\
\hline $\begin{array}{l}\text { Public health expenditures (in logs, share of GDP) does not Granger Cause GN } \\
\text { in logs) }\end{array}$ & capita & 1.87869 & 0.0823 \\
\hline
\end{tabular}

Lags: 2

Null Hypothesis:

Obs F-Statistic Prob.

GNI per capita (in logs) does not Granger Cause Public social protection spending (in logs, share of GDP) 834 Public social protection spending (in logs, share of GDP) does not Granger Cause GNI per capita (in logs)

Causality between public educational spending (in logs, share in GDP) and expected years of schooling (in logs)

Lags: 6

Null Hypothesis:

Obs F-Statistic Prob. 
Public educational expenditures (in logs, share of GDP) does not Granger Cause Expected years of schooling (in logs)

Causality between public health spending (in logs, share in GDP) and life expectancy

Lags: 6

Null Hypothesis:

Obs F-Statistic Prob.

Public health expenditures (in logs, share of GDP) does not Granger Cause Life expectancy (in logs)

Life expectancy i(n logs) does not Granger Cause Public health expenditures (in logs, share of GDP)

Lags: 8

Null Hypothesis:

Obs F-Statistic

Prob.

Public health expenditures (in logs, share of GDP) does not Granger Cause Life expectancy (in logs) 565 Life expectancy (in logs) does not Granger Cause Public health expenditures (in logs, share of GDP) 


\section{APPENDIX III. PUblic Social SPENDING by Regions ANd LeVEl of INCOME (FIGURES)}

Figure 6. Social Protection Spending by Regions for 2016 (percent of GDP)

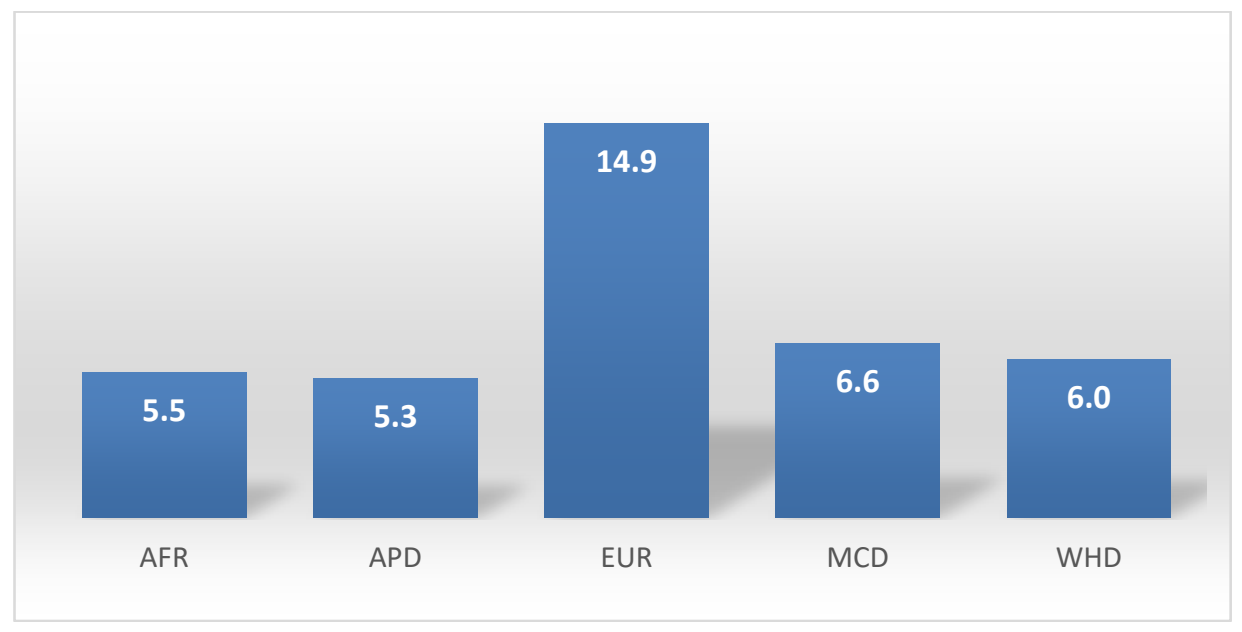

AFR (Sub-Saharan Africa); APD (Asia and Pacific); EUR (Europe), MCD (North Africa and Middle East); WHD (Western Hemisphere)

Source: Authors’ estimates from Government Finance Statistics Database, 2019

Figure 7. Social Protection by Countries Income Level for 2016 (percent of GDP)

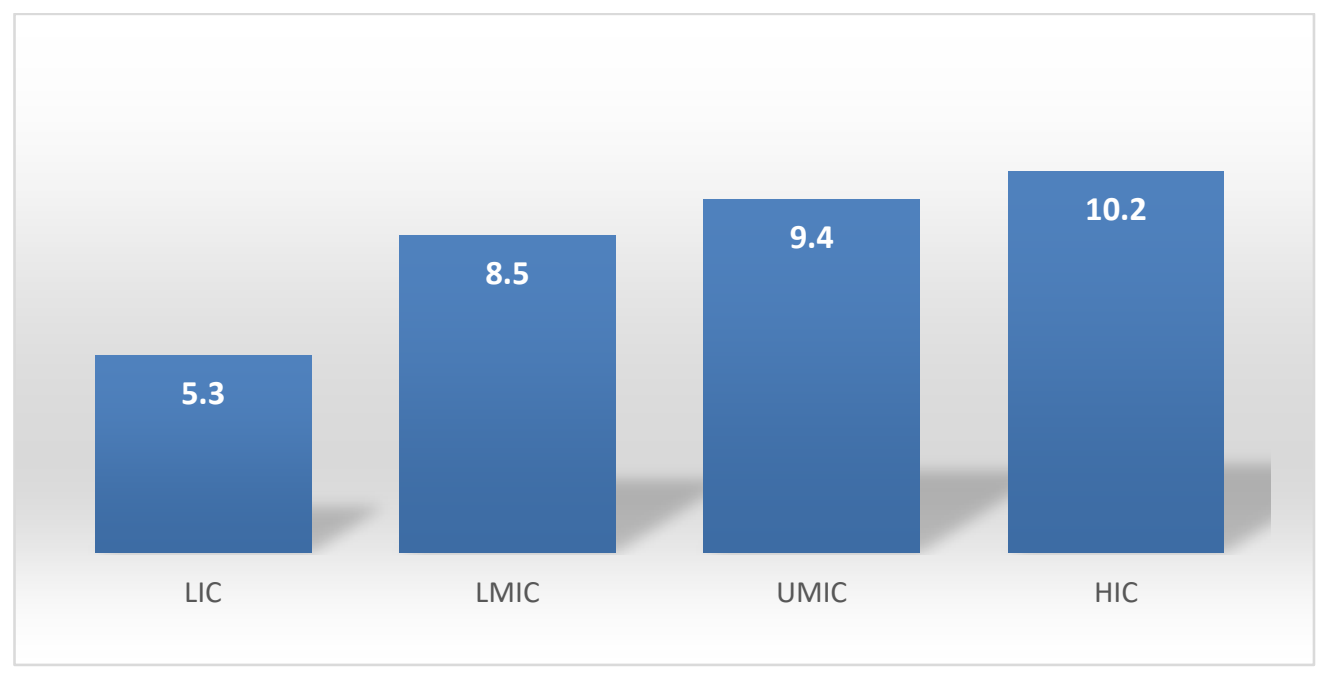

LIC (Low Income Countries); LMIC (Lower Middle Income); UMIC (Upper Middle Income); HIC (High Income)

Source: Authors’ estimates from Government Finance Statistics Database, 2019 
Figure 8. Educational spending by Regions for 2016 (percent of GDP)

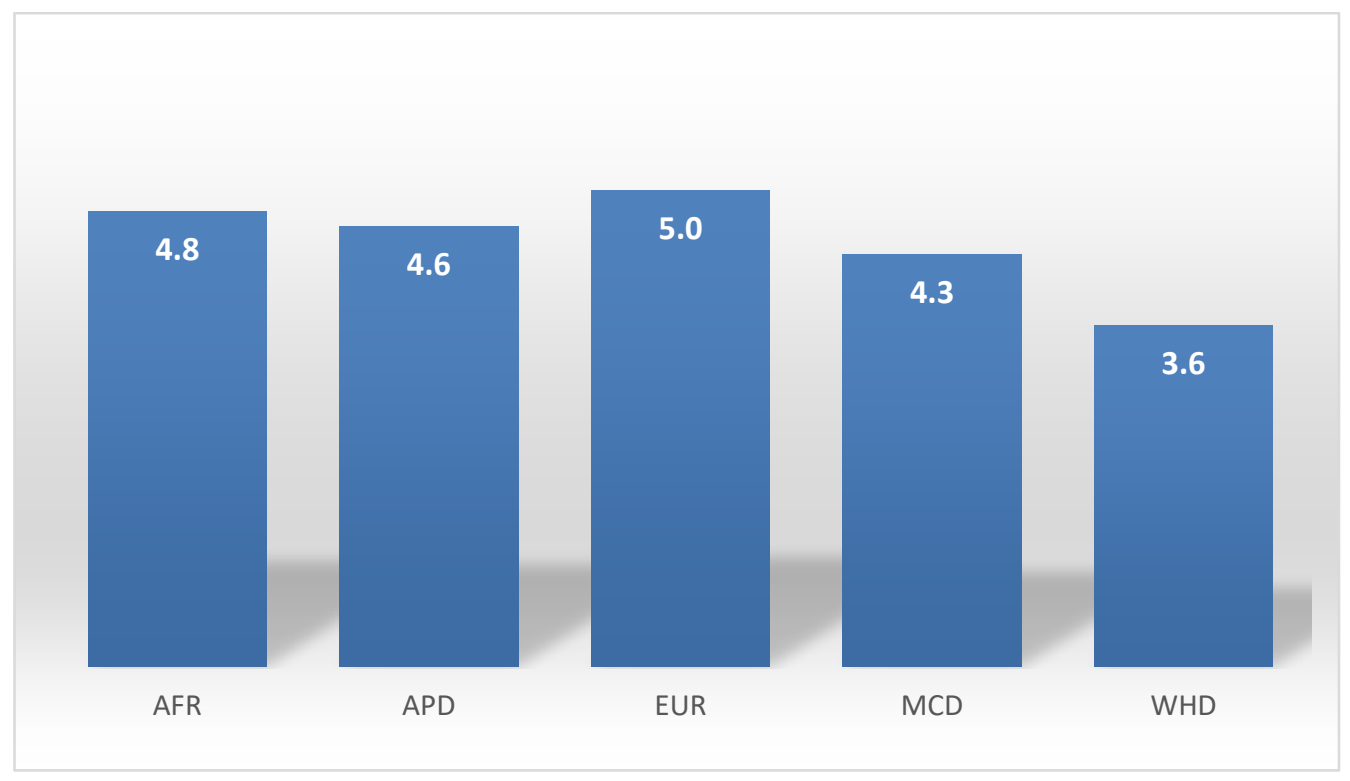

AFR (Sub-Saharan Africa); APD (Asia and Pacific); EUR (Europe), MCD (North Africa and Middle East); WHD (Western Hemisphere)

Source: Authors' estimates from Government Finance Statistics Database, 2019

Figure 9. Educational spending by Countries Income Level for 2016 (percent of GDP)

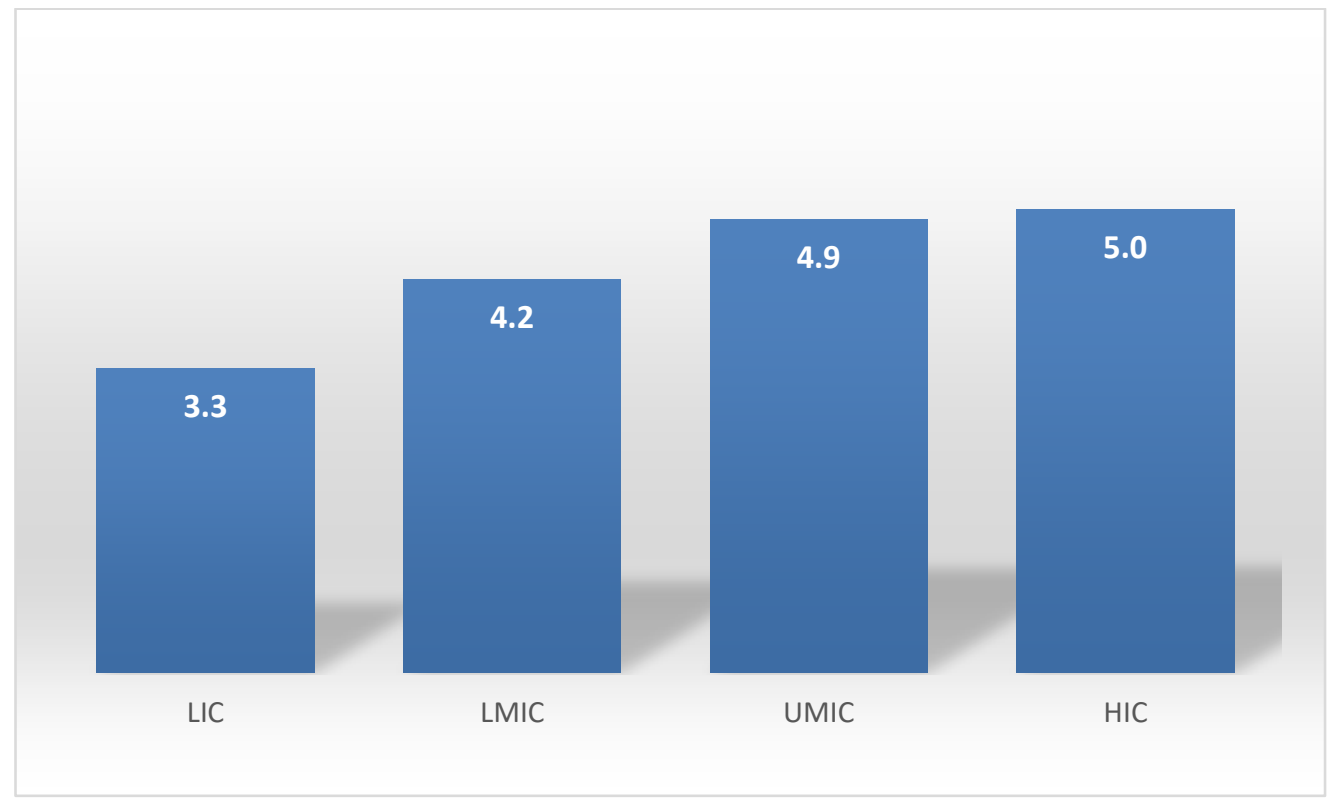

LIC (Low Income Countries); LMIC (Lower Middle Income); UMIC (Upper Middle Income); HIC (High Income)

Source: Authors’ Estimates from Government Finance Statistics Database, 2019 
Figure 10. Health Spending by Regions for 2016 (percent of GDP)

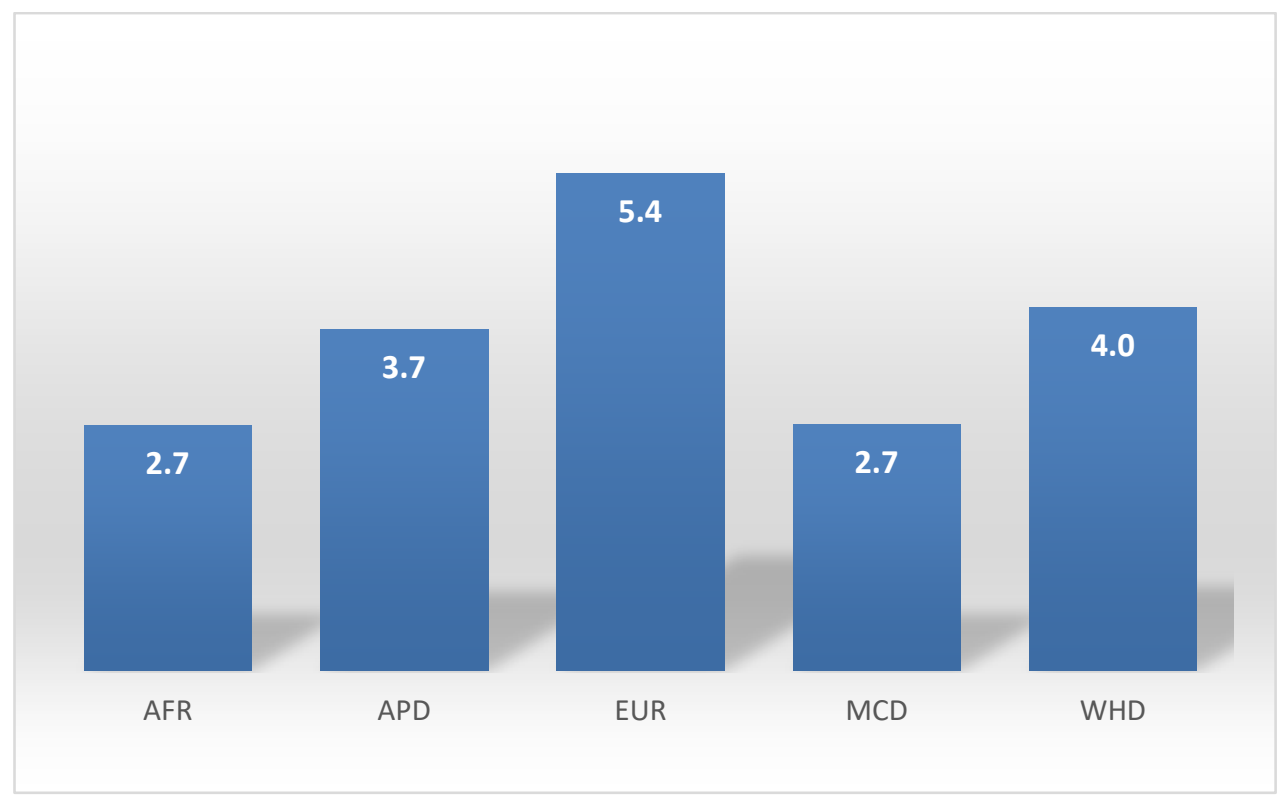

AFR (Sub-Saharan Africa); APD (Asia and Pacific); EUR (Europe), MCD (North Africa and Middle East); WHD (Western Hemisphere)

Source: Author's estimates from Government Finance Statistics Database, 2019

Figure 11. Health Spending by Countries Income Level for 2016 (percent of GDP)

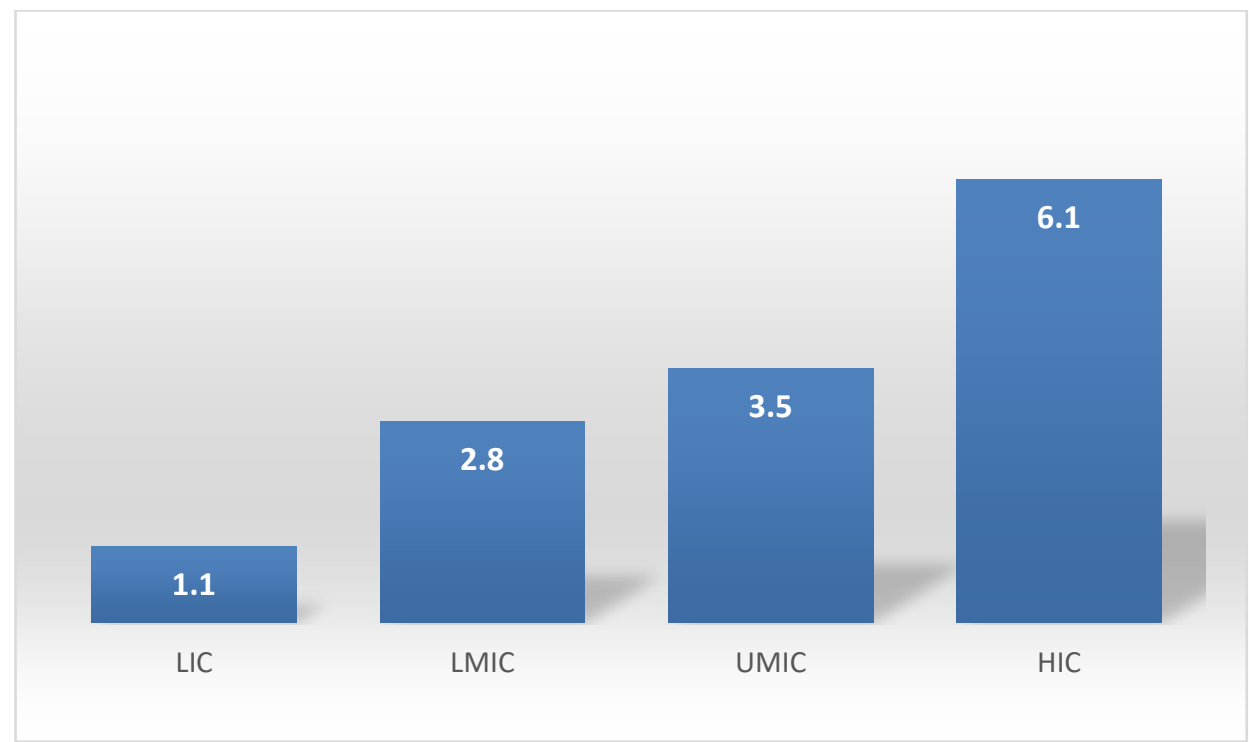

LIC (Low Income Countries); LMIC (Lower Middle Income); UMIC (Upper Middle Income); HIC (High Income)

Source: Authors' estimates from Government Finance Statistics Database, 2019 